\title{
Flux variability of phyto- and zooplankton communities in the Mauritanian coastal upwelling between 2003 and 2008
}

\author{
Oscar E. Romero ${ }^{1}$, Karl-Heinz Baumann ${ }^{1,2}$, Karin A. F. Zonneveld ${ }^{1}$, Barbara Donner ${ }^{1}$, Jens Hefter ${ }^{3}$, \\ Bambaye Hamady $^{4}$, Vera Pospelova ${ }^{5,6}$, and Gerhard Fischer ${ }^{1,2}$ \\ ${ }^{1}$ MARUM - Center for Marine Environmental Sciences, University of Bremen, Leobener Str. 8, 28359 Bremen, Germany \\ ${ }^{2}$ Department of Geosciences, University of Bremen, Klagenfurter Str. 2-4, 28359 Bremen, Germany \\ ${ }^{3}$ Alfred Wegener Institute, Helmholtz Centre for Polar and Marine Research, 27568 Bremerhaven, Germany \\ ${ }^{4}$ IMROP, Institut Mauretanien de Recherches Océanographiques et des Pêches, BP 22, Nouadhibou, Mauritania \\ ${ }^{5}$ Department of Earth and Environmental Sciences, University of Minnesota, College of Science and Engineering, \\ 116 Church Street SE, Minneapolis, MN 55455, USA \\ ${ }^{6}$ School of Earth and Ocean Sciences, University of Victoria, OEASB A405, P.O. Box 170016 STN CSC, \\ Victoria, British Columbia, V8W 2Y2, Canada
}

Correspondence: Oscar E. Romero (oromero@marum.de, oromero@uni-bremen.de)

Received: 12 August 2019 - Discussion started: 27 August 2019

Revised: 18 November 2019 - Accepted: 30 November 2019 - Published: 17 January 2020

\begin{abstract}
Continuous multiyear records of sediment-trapgained microorganism fluxes are scarce. Such studies are important to identify and to understand the main forcings behind seasonal and multiannual evolution of microorganism flux dynamics. Here, we assess the long-term flux variations and population dynamics of diatoms, coccolithophores, calcareous and organic dinoflagellate cysts, foraminifera and pteropods in the eastern boundary upwelling ecosystem of the Canary Current. A multiannual, continuous sediment trap experiment was conducted at the mooring site CBeu (Cap Blanc eutrophic; $\sim 20^{\circ} \mathrm{N}, 18^{\circ} \mathrm{W}$; trap depth is ca. $1300 \mathrm{~m}$ ) off Mauritania (northwest Africa), between June 2003 and March 2008. Throughout the study, the reasonably consistent good match of fluxes of microorganisms and bulk mass reflects the seasonal occurrence of the main upwelling season and relaxation and the contribution of microorganisms to mass flux off Mauritania. A clear successional pattern of microorganisms, i.e., primary producers followed by secondary producers, is not observed. High fluxes of diatoms, coccolithophores, organic dinoflagellate cysts, and planktonic foraminifera occur simultaneously. Peaks of calcareous dinoflagellate cysts and pteropods mostly occurred during intervals of upwelling relaxation. A striking feature of the temporal variability of population occurrences is the persistent pattern of seasonal groups contributions. Species of
\end{abstract}

planktonic foraminifera, diatoms, and organic dinoflagellate cysts typical of coastal upwelling, as well as cooler-water planktonic foraminifera and the coccolithophore Gephyrocapsa oceanica, are abundant at times of intense upwelling (late winter through early summer). Planktonic foraminifera and calcareous dinoflagellate cysts are dominant in warm pelagic surface waters, and all pteropod taxa are more abundant in fall and winter when the water column stratifies. Similarly, coccolithophores of the upper and lower photic zones, together with Emiliania huxleyi, and organic dinoflagellate cysts dominate the assemblage during phases of upwelling relaxation and deeper layer mixing.

A significant shift in the "regular" seasonal pattern of taxa relative contribution is observed between 2004 and 2006. Benthic diatoms strongly increased after fall 2005 and dominated the diatom assemblage during the main upwelling season. Additional evidence for a change in population dynamics is the short dominance of the coccolithophore Umbilicosphaera annulus, the occurrence of the pteropod Limacina bulimoides and the strong increase in the flux of calcareous dinoflagellate cysts, abundant in warm tropical oligotrophic waters south of the study area after fall 2005. Altogether, this suggests that pulses of southern waters were transported to the sampling site via the northward Mauritania Current. Our multiannual trap experiment provides a unique opportunity 
to characterize temporal patterns of variability that can be extrapolated to other eastern boundary upwelling ecosystems (EBUEs), which are experiencing or might experience similar future changes in their plankton community.

\section{Introduction}

A way to obtain insights into the impact of climate variability on marine ecosystems is monitoring multiannual evolution and changes covering key species or groups of species representing different trophic levels. To date, multiyear continuous in situ monitoring records of marine communities are scarce. Information about open-ocean ecosystems is even more rare (e.g., IOC-UNESCO TS129 IGMETS, 2017; Bringué et al., 2019). Furthermore, records providing information about organism groups of different trophic levels are practically unknown or cover only a few species (e.g., Schlüter et al., 2012; Rembauville et al., 2016).

Eastern boundary upwelling ecosystems (EBUEs) are among the most important marine ecosystems, both ecologically and economically (Cropper et al., 2014). Despite the fact that they cover only $10 \%$ of the global surface ocean area, they provide about $25 \%$ of the global fish catch (Pauly and Christensen, 1995) and build extraordinary marine hotspots of high primary production and biodiversity (Arístegui et al., 2009). In doing so, they play a key role in the marine biological pump, and, together with other continental margins, they may be responsible for more than $40 \%$ of the $\mathrm{CO}_{2}$ ocean sequestration (Muller-Karger et al., 2005). As EBUEs are highly dynamic with large seasonal and interannual variability (e.g., Chavez and Messié, 2009; Fischer et al., 2016), gaining information on their long-term variability is essential to understand their potential response to current global climate change.

One of the EBUEs that have been thoroughly studied over the past 3 decades is the coastal ecosystem off Mauritania (northwest Africa), which is part of the Canary Current (CC) EBUE (Cropper et al., 2014). The Mauritanian system is characterized by intense offshore Ekman transport and strong mesoscale heterogeneity, which facilitate the exchange of neritic and pelagic water masses (Mittelstaedt, 1983; Zenk et al., 1991; Van Camp et al., 1991; Arístegui et al., 2009; Chavez and Messié, 2009; Meunier et al., 2012; Cropper et al., 2014). In addition, regional factors such as nutrient trapping efficiency (Arístegui et al., 2009), the giant chlorophyll filament (Gabric et al., 1993; Barton, 1998; Lange et al., 1998; Helmke et al., 2005), dust deposition (Fischer et al., 2016, 2019) and/or the shelf width (Hagen, 2001; Cropper et al., 2014) strongly affect the temporal dynamics of primary and secondary producer communities in surface waters along the Mauritanian coast. In this ecosystem, several long-term continuous sediment-trap-based monitoring records are available since the late 1980s. Until now, stud- ies monitoring variability of this seasonally dynamic ecosystem mostly focused on the variability of bulk fluxes (Fischer et al., 1996, 2009, 2016, 2019; Bory et al., 2001; Marcello et al., 2011; Skonieczny et al., 2013), particular groups of microorganisms (Lange et al., 1998; Romero et al., 1999, 2002, 2003; Köbrich and Baumann, 2008; Romero and Armand, 2010; Zonneveld et al., 2010; Köbrich et al., 2016; Romero and Fischer, 2017; Guerreiro et al., 2019) or seasurface temperature (Müller and Fischer, 2001; Mollenhauer et al., 2015). However, the simultaneous comparison of the seasonal and interannual dynamics of several phyto- and zooplankton communities by means of multiyear sediment trap experiments has not been performed in this region and is rare in other EBUEs or other ocean areas as well (Bringué et al., 2019).

This paper builds on the long-term studies of the variability of sea-surface temperature (SST) and fluxes at the site CBeu published by Mollenhauer et al. (2015), Romero and Fischer (2017), and Fischer et al. (2019). We describe the seasonal and interannual variability of fluxes of several primary and secondary producers in the Mauritanian coastal upwelling over a continuous trap experiment extending almost 1900 d between June 2003 and March 2008 (Table 1). In addition to the previously reported diatom fluxes and reconstructed SST values, we present here new data of fluxes of coccolithophores, calcareous and organic-walled dinoflagellate cysts, planktonic foraminifera, and pteropods as well as the species-specific composition of the assemblages that have been collected at the mooring site CBeu (Cap Blanc eutrophic), located around $80 \mathrm{nmi}$ west of the Mauritanian coastline below a giant chlorophyll filament (Fig. 1). The microorganisms producing the calcareous, opaline or organic remains have different water column habitats and life strategies and use different nutrient sources (Romero et al., 1999, 2002; Baumann et al., 2005; Romero and Armand, 2010; Zonneveld et al., 2013), and they are widely used as proxies in paleostudies carried out on Mauritanian sediments (Jordan et al., 1996; Romero et al., 2008; McKay et al., 2014) and similar paleoenvironments (e.g., Baumann and Freitag, 2004; Bouimetarhan et al., 2009; Romero et al., 2015; Weiser et al., 2016; Hardy et al., 2018). The emphasis of our multiannual trap experiment is on the comparison of temporal dynamics and the species-specific composition of the primary and secondary producer plankton community off Mauritania. The simultaneous assessment of fluxes of several microorganism groups collected over long intervals provides substantial information about potential changes in the coastal upwelling community. Results are discussed in the context of varying environmental conditions of the low-latitude northeastern Atlantic. To our knowledge, this is the first multiyear trap-based record of major primary and secondary producers that provides multiyear information on the dynamics of major components of the plankton community in a highly productive EBUE. 


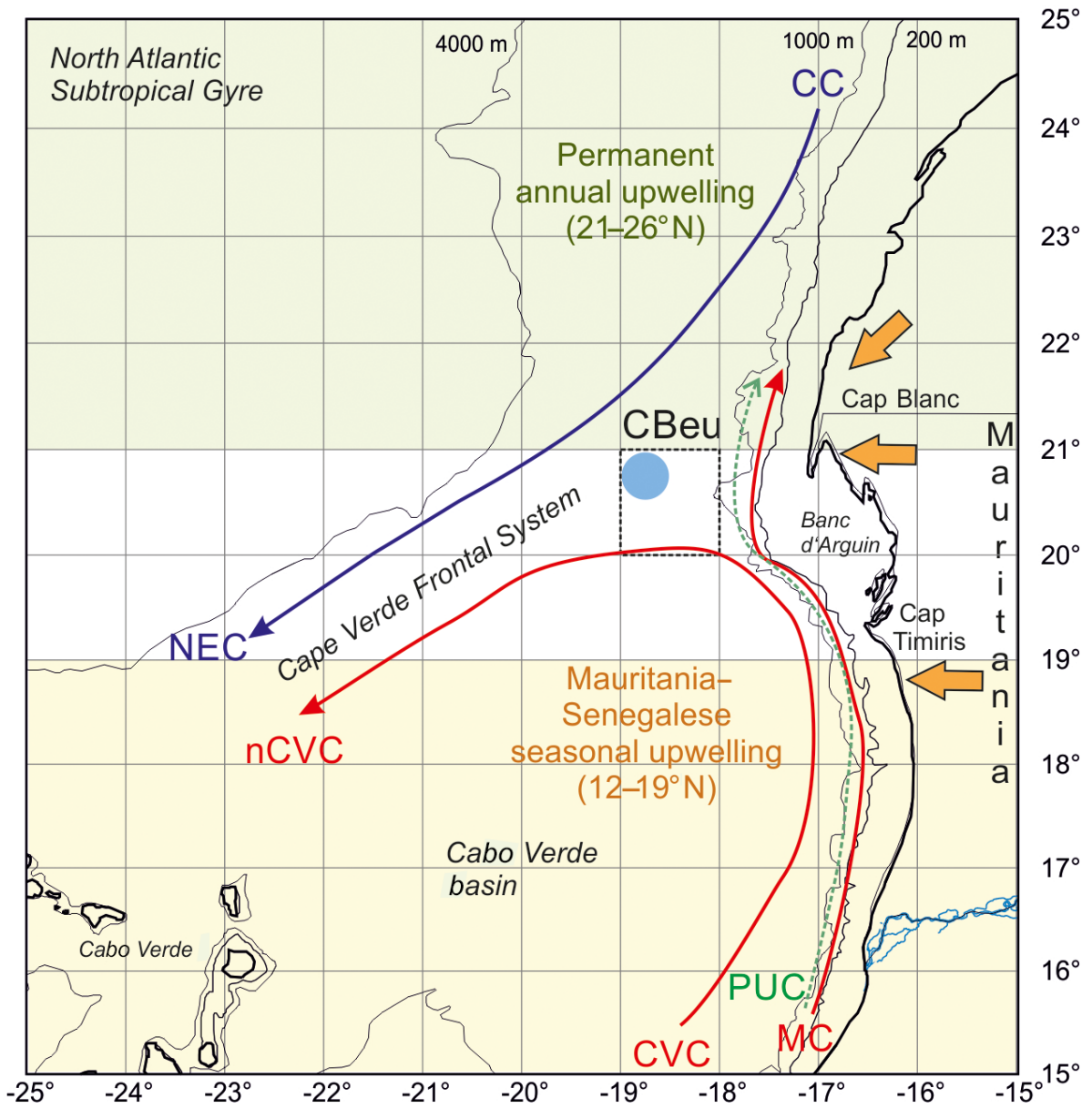

Figure 1. Map of the study area showing the location of trap site CBeu (full light blue dot), surface currents and main wind system. Surface currents (Canary Current, CC, violet line; North Equatorial Countercurrent, blue arrow; Mauritanian Current, red arrow), North Equatorial Current (NEC), Cape Verde Current (CVC), north Cape Verde Current (nCVC) and Poleward Undercurrent (PUC) are depicted after Mittelstaedt $(1983,1991)$ and Zenk et al. (1991). The Cape Verde Frontal Zone (CVFZ) builds at the confluence of the NACW and the SACW (Zenk et al., 1991). Trade winds and the Saharan air layer are represented by orange arrows (Nicholson, 2013). The upwelling zones are depicted after Cropper et al. (2014).

\section{Oceanographic setting of the study area}

The CC-EBUE is located in the eastern part of the North Atlantic Subtropical Gyre (Fig. 1; Arístegui et al., 2009; Chavez and Messié, 2009; Cropper et al., 2014). Both the temporal occurrence and the intensity of the upwelling along northwestern Africa depend on the shelf width, the seafloor topography, and wind direction and strength (Mittelstaedt, 1983; Hagen, 2001). The Mauritanian shelf is wider than the shelf northward and southward and gently slopes from the coastline into water depths below $200 \mathrm{~m}$ (Fig. 1b; Hagen, 2001). The shelf break zone with its steep continental slope extends over a distance of approximately $100 \mathrm{~km}$ (Hagen, 2001). As a result of the coastal and shelf slope topography and the ocean currents and wind systems, the coastal region off Mauritania is characterized by almost permanent upwelling. Its intensity varies throughout the year (Lathuilière et al., 2008; Cropper et al., 2014). Our trap site CBeu is located at the southern boundary of this permanent upwelling zone (Fig. 1; Table 1).

The surface hydrography is strongly influenced by two wind-driven surface currents: the southwestward-flowing CC and the poleward-flowing coastal countercurrent or Mauritania Current (MC) (Fig. 1). The eastern branch of the subtropical gyre, the surficial CC, detaches from the continental slope between 25 and $21^{\circ} \mathrm{N}$ and supplies waters to the North Equatorial Current. The $\mathrm{CC}$ water is relatively cool because it entrains upwelled water from the coast as it moves southward (Mittelstaedt, 1991). The MC gradually flows northward along the coast up to about $20^{\circ} \mathrm{N}$ (Mittelstaedt, 1991), bringing warmer surface waters from the equatorial realm into the study area. Towards late autumn, the MC is gradually replaced by a southward flow associated with upwelling water due to the increasing influence of trade winds south of $20^{\circ} \mathrm{N}$ (Zenk et al., 1991), and it becomes a narrow strip of 
Table 1. Data deployment at site CBeu (Cap Blanc eutrophic, off Mauritania): coordinates, GeoB location and cruise, trap depth, ocean bottom depth, sample amount, capture duration of each sample, and sampling interval. Two gaps in the sampling intervals occurred: 518 April 2004 and 28 September-28 October 2006.

\begin{tabular}{|c|c|c|c|c|c|c|c|}
\hline $\begin{array}{l}\text { Mooring } \\
\text { CBeu }\end{array}$ & Coordinates & $\begin{array}{l}\text { GeoB no. } \\
\text { and cruise }\end{array}$ & $\begin{array}{r}\text { Trap depth } \\
(\mathrm{m})\end{array}$ & $\begin{array}{r}\text { Ocean bottom } \\
\text { depth }(\mathrm{m})\end{array}$ & $\begin{array}{l}\text { Sample } \\
\text { amount }\end{array}$ & $\begin{array}{l}\text { Capture duration } \\
\text { (sample no. = days) }\end{array}$ & Sampling interval \\
\hline 1 & $\begin{array}{l}20^{\circ} 45^{\prime} \mathrm{N} \\
18^{\circ} 42^{\prime} \mathrm{W}\end{array}$ & POS 310 & 1296 & 2714 & 20 & $1=10.5,2-20=15.5$ & 5 Jun 2003-5 Apr 2004 \\
\hline 2 & $\begin{array}{l}20^{\circ} 45^{\prime} \mathrm{N} \\
18^{\circ} 42^{\prime} \mathrm{W}\end{array}$ & $\begin{array}{l}9630-2 \\
\text { M 65-2 }\end{array}$ & 1296 & 2714 & 20 & $1-20=22,2-19=23$ & 18 Apr 2004-20 Jul 2005 \\
\hline 3 & $\begin{array}{l}20^{\circ} 45.5^{\prime} \mathrm{N} \\
18^{\circ} 41.9^{\prime} \mathrm{W}\end{array}$ & $\begin{array}{l}11404-3 \\
\text { POS 344-1 }\end{array}$ & 1277 & 2693 & 20 & 21.5 & $25 \mathrm{Jul}$ 2005-28 Sep 2006 \\
\hline 4 & $\begin{array}{l}20^{\circ} 45.7^{\prime} \mathrm{N} \\
18^{\circ} 42.4^{\prime} \mathrm{W}\end{array}$ & $\begin{array}{l}11835-2 \\
\text { MSM 04b }\end{array}$ & 1256 & 2705 & 20 & $1=3.5,2-20=7.5$ & 28 Oct 2006-23 Mar 2007 \\
\hline 5 & $\begin{array}{l}20^{\circ} 44.9^{\prime} \mathrm{N} \\
18^{\circ} 42.7^{\prime} \mathrm{W}\end{array}$ & $\begin{array}{l}12910-2 \\
\text { POS 365-2 }\end{array}$ & 1263 & 2709 & 38 & $1,2=6.5,3-38=9.5$ & 28 Mar 2007-17 Mar 2008 \\
\hline
\end{tabular}

less than $100 \mathrm{~km}$ width in winter (Mittlelstaedt, 1983). The MC advances onto the shelf during summer and is enhanced by the relatively strong North Equatorial Countercurrent and the southerly monsoon (Mittelstaedt, 1983). The presence of strong coastal currents during the upwelling season causes substantial horizontal shear within the surface layer, where currents tend to converge (Mittelstaedt, 1983). This convergence favors the formation of the Cape Verde Frontal Zone (CVFZ, Fig. 1; Zenk et al., 1991).

A coastal countercurrent, the Poleward Undercurrent (PUC; Fig. 1), occurs mainly due to wind-driven offshore divergence (Pelegrí et al., 2017). North of Cap Blanc (ca. $21^{\circ} \mathrm{N}$ ), the intense northeasterly winds cause the coastal upwelling to move further offshore and the upper slope is filled with upwelled waters. South of Cap Blanc, northerly winds dominate throughout the year, but surface waters remain stratified and the PUC occurs as a subsurface current. South of Cap Timiris (ca. $19^{\circ} 30^{\prime} \mathrm{N}$ ), the PUC intensifies during summer/fall and remains at the subsurface during winter/spring (Pelegrí et al., 2017). The encountering of the northward-flowing MC-PUC system with the southward flowing currents in the Canary Basin leads to flow confluence at the CVFZ (Zenk et al., 1991) and the offshore water export visible as the giant Mauritanian chlorophyll filament (Gabric, 1993; Pelegrí et al., 2006, 2017). This filament extends over $300 \mathrm{~km}$ offshore (e.g., Van Camp et al., 1991; Arístegui et al., 2009; Cropper et al., 2014) and carries South Atlantic Central Water (SACW) offshore through an intense jet-like flow (Meunier et al., 2012; Fig. 1). Intense offshore transport forms an important mechanism for the export of cool nutrient-rich shelf and upper slope waters offshore Mauritania. Based on satellite imagery and in situ data, it has been estimated that the giant Mauritanian filament could export about $50 \%$ of the particulate coastal new production offshore toward the open ocean during intervals of most intense up- welling, while coastal phytoplankton at the surface might be transported as far as $400 \mathrm{~km}$ offshore (Gabric et al., 1993; Barton, 1998; Lange et al., 1998; Helmke et al., 2005). The transport effect could extend to even more distant regions in the deep ocean, since sinking particles are strongly advected by lateral transport (Fischer and Karakaş, 2009; Karakaş et al., 2006; Fischer et al., 2009).

The nutrient concentration of the upwelled waters off Mauritania varies depending on its origin (Fütterer, 1983; Mittelstaedt, 1991; Zenk et al., 1991). The sources of upwelling waters off Mauritania are either North Atlantic Central Water (NACW), north of about $23^{\circ} \mathrm{N}$, or SACW (south of $21^{\circ} \mathrm{N}$, Fig. 1). Both water masses are mixed in the filament area off Cap Blanc. The SACW occurs in layers between 100 and $400 \mathrm{~m}$ depth off Cap Blanc and the Banc d'Arguin. The hydrographic properties of the upwelling waters on the shelf suggest that they ascend from depths between 100 and $200 \mathrm{~m}$ south off the Banc d'Arguin (Mittelstaedt, 1983). North of it, the SACW merges gradually into deeper layers (200-400 m) below the CC (Mittelstaedt, 1983). During intense upwelling, the stratification of the shelf waters weakens and so does the stratification further offshore, usually within the upper $100 \mathrm{~m}$ (Mittelstaedt, 1991). The biological response is drastically accelerated in the upwelling waters when the SACW of the upper part of the undercurrent feeds the onshore transport of intermediate layers to form mixed-water types on the shelf (Zenk et al., 1991).

\section{Material and methods}

\subsection{Moorings, sediment traps and bulk flux assessment}

Sediment trap moorings were deployed at site CBeu off Mauritania in the CC-EBUE (Fig. 1). Details on trap location and depth, sample amount, water depth and sampling intervals as 
well as the sample identification (cruise and GeoB numbers) are presented in Table 1. Large-aperture time-series sediment traps of the Kiel type were used with 20 to 40 cups (depending on ship time availability) and $0.5 \mathrm{~m}^{2}$ openings, equipped with a honeycomb baffle (Kremling et al., 1996). Traps were moored in intermediate waters (1256-1296 m) and sampling intervals varied between 6.5 and $23 \mathrm{~d}$ (Table 1). Uncertainties with the trapping efficiency due to strong currents (e.g., undersampling) and/or due to the migration and activity of zooplankton migrators ("swimmer problem") are assumed to be minimal in the depth range of our trap experiments (Buesseler et al., 2007; Fischer et al., 2019).

Prior to each deployment, sampling cups were poisoned with $1 \mathrm{~mL}$ of concentrated $\mathrm{HgCl}_{2}$ per $100 \mathrm{~mL}$ of filtered seawater. Pure $\mathrm{NaCl}$ was used to increase the density in the sampling cups up to $40 \%$. Upon recovery, samples were stored at $4{ }^{\circ} \mathrm{C}$ and wet split in the MARUM sediment trap laboratory (University Bremen, Bremen) using a rotating McLane wet splitter system. Larger swimmers, such as crustaceans, were handpicked with forceps and removed by carefully filtering through a $1 \mathrm{~mm}$ sieve. All flux data hereafter refer to the size fraction of $<1 \mathrm{~mm}$. Detailed information about sampling and laboratory analysis is given in Mollenhauer et al. (2015), Romero and Fischer (2017) and Fischer et al. (2019). These papers present the bulk fluxes for the deployments CBeu 1-5 (Table 1). Alkenone-derived sea surface temperature (SST) for the CBeu deployments 1-4 were provided by Mollenhauer et al. (2015).

Using $1 / 4$ or $1 / 5$ wet splits, analysis of the $<1 \mathrm{~mm}$ fraction was carried out (Fischer and Wefer, 1991; Fischer et al., 2016). Samples were freeze-dried and homogenized before being analyzed for bulk (total mass), organic carbon (OC), calcium carbonate $\left(\mathrm{CaCO}_{3}\right)$ and biogenic silica $(\mathrm{BSi}$, opal). Total organic carbon (TOC) and $\mathrm{CaCO}_{3}$ were measured by combustion with a CHN analyzer (HERAEUS, Department of Geosciences, University of Bremen). TOC was measured after removal of carbonate with $2 \mathrm{~N} \mathrm{HCl}$. Overall analytical precision based on internal lab standards was better than $0.1 \%( \pm 1 \sigma)$. Carbonate was determined by subtracting OC from total carbon, the latter being measured by combustion without pretreatment with $2 \mathrm{~N} \mathrm{HCl}$. Organic matter was estimated by multiplying the content of total organic carbon by a factor of 2 as about $50 \%-60 \%$ of marine organic matter is constituted by OC (Hedges et al., 2002).

$\mathrm{BSi}$ was determined with a sequential leaching technique with $1 \mathrm{M} \mathrm{NaOH}$ at $85^{\circ} \mathrm{C}$ (Müller and Schneider, 1993). The precision of the overall method based on replicate analyses is mostly between $\pm 0.2 \%$ and $\pm 0.4 \%$, depending on the material analyzed. The lithogenic fluxes were estimated by subtracting the masses of $\mathrm{CaCO}_{3}, \mathrm{BSi}$ and two times $\mathrm{OC}$ from the total mass flux.

\subsection{Assessment of organism fluxes and species identification}

\subsubsection{Diatoms}

Diatom data shown here were previously published in Romero and Fischer (2017). For this study $1 / 25$ and 1/125 splits of the original samples were used. Samples were prepared for diatom studies following the method proposed by Schrader and Gersonde (1978). A total of 185 sediment trap samples were processed. Each split was treated with potassium permanganate, hydrogen peroxide and concentrated hydrochloric acid following a previously used methodology (Romero et al., 2002, 2009a, b, 2016, 2017). Identification and counting of the species assemblage were done on permanent slides (Mountex mounting medium) at 1000× magnification using a Zeiss Axioscop with phase-contrast illumination (MARUM, Bremen). The counting procedure and definition of counting units follows Schrader and Gersonde (1978). Depending on valve abundances in each sample, several traverses across each slide were examined. Total amount of counted valves per slide ranged between 300 and 800 . At least two cover slips per sample were scanned in this way. Valve counts of replicate slides indicate that the analytical error of concentration estimates is ca. $10 \%$. The resulting counts yielded the abundance of individual diatom taxa (absolute and relative) as well as daily fluxes of diatoms as valves in units of square meters per day $\left(\mathrm{m}^{-2} \mathrm{~d}^{-1}\right)$, calculated according to Sancetta and Calvert (1988).

\subsubsection{Coccolithophores}

Aliquots of each sample were 1/125. Depending on the total flux, samples were further split down to $1 / 625$ to $1 / 2500$ of the original sample volume and were filtered afterward onto polycarbonate membrane filters (Schleicher and Schuell ${ }^{\mathrm{TM}}$ $47 \mathrm{~mm}$ diameter, $0.45 \mu \mathrm{m}$ pore size). A piece of the filter was cut and mounted on a scanning electron microscopy stub. Qualitative and quantitative analyses of the trapped assemblages were performed using a Zeiss DSM 940A at $10 \mathrm{kV}$ accelerating voltage (Department of Geosciences, University of Bremen, Bremen). In an arbitrarily chosen transect, coccoliths were counted until a total of at least 500 specimens were reached. The taxonomic classification of identified species was based on Young et al. (2003) as well as on Nannotax 3 (Young et al., 2019).

\subsubsection{Calcareous and organic-walled dinoflagellate cysts}

$1 / 125$ splits of the original trap material were ultrasonically treated and sieved with tap water through a highprecision metal sieve (Stork Veco) with a $20 \mu \mathrm{m}$ pore size. The residue was transferred to Eppendorff cups and concentrated to $1 \mathrm{~mL}$ of suspension. After homogenization of the material, a known aliquot was transferred to a microscope 
slide where it was embedded in glycerin gelatine, covered with a cover slip and sealed with wax to prevent oxidation of the organic material. After counting, cyst fluxes were calculated by multiplying the cyst counts with the aliquot fraction and the split size $(1 / 125)$ and dividing through the amount of days during which the trap material was sampled as well as the trap-capture surface. No chemicals were used to prevent dissolution of calcite and silicate. Cyst assemblages were determined by light microscopy (Zeiss Axiovert, 400× magnification). The taxonomy of calcareous dinoflagellate cysts follows Vink et al. (2002) and Elbrächter et al. (2008), while that of organic-walled dinoflagellate cysts is according to Zonneveld and Pospelova (2015).

\subsubsection{Planktonic foraminifera and pteropods}

Depending on the absolute magnitude of the total mass flux, a $1 / 5$ or a $1 / 25$ split of the wet solution (fraction $<1 \mathrm{~mm}$ ) was used to pick planktonic foraminifera and pteropods (pelagic mollusks). Specimens of both groups of calcareous microorganisms were rinsed three times by using tap water, dried at $50^{\circ} \mathrm{C}$ in an oven overnight and then separated from each other. Identification and counting of shells were done by using a Zeiss Stemi 2000 stereomicroscope (MARUM, Bremen). The foraminifera fluxes (all size fractions) were determined in milligrams per square meter per day $\left(\mathrm{mg} \mathrm{m}^{-2} \mathrm{~d}^{-1}\right)$ with a Sartorius BP 211D analytical balance. Additionally, the total amount of specimens or sample of foraminifera and pteropods $(>150 \mu \mathrm{m})$ was manually counted. Planktonic foraminifera were identified and classified according to Hemleben et al. (1989) and Schiebel and Hemleben (2017). Out of 15 species of planktonic foraminifera identified, only 6 species were used as environmental indicators.

\subsubsection{Alkenones}

$1 / 5$ wet splits of the $<1 \mathrm{~mm}$ fraction were used for alkenone analysis. Briefly, freeze-dried CBeu 1-4 samples were solvent extracted. The resulting total lipid extracts (TLEs) saponified and the alkenone fractions were obtained by means of column chromatography of the neutral lipid fractions from the saponification. Details are given in Mollenhauer et al. (2015).

A slightly different, miniaturized analysis procedure has been applied for the CBeu trap 5 samples. 1/5 wet splits of the freeze-dried $<1 \mathrm{~mm}$ fraction were weighted in $10 \mathrm{~mL}$ Pyrex tubes and a known amount of an internal standard (n-nonadecan-2-one) was added. Samples were then three times ultrasonically extracted with a mixture of $3 \mathrm{~mL}$ dichloromethane/methanol (9:1 vol./vol.), centrifuged and the supernatant solvent combined as total lipid extract (TLE). TLEs were evaporated to dryness and saponified in a $0.1 \mathrm{M}$ potassium hydroxide solution in methanol/water $\left(9: 1\right.$ vol./vol.) for $2 \mathrm{~h}$ at $80^{\circ} \mathrm{C}$. Neutral lipids, recovered with hexane, were afterwards separated into fractions of different polarity by silica gel chromatography and elution with hexane, dichloromethane/hexane (1: 1 vol./vol.) and dichloromethane/methanol (9: 1 vol./vol.), respectively. The second fraction containing the alkenones was dried, redissolved in $20 \mu \mathrm{L}$ hexane and analyzed on a 7890A gas chromatograph (GC, Agilent Technologies) equipped with a cold on-column injection system, a DB-5MS fused silica capillary column $(60 \mathrm{~m}$, i.d. $250 \mu \mathrm{m}, 0.25 \mu \mathrm{m}$ film coupled to a $5 \mathrm{~m}$, i.d. $530 \mu \mathrm{m}$ deactivated fused silica precolumn) and a flame ionization detector (FID). Helium was used as carrier gas (constant flow, $1.5 \mathrm{~mL} \mathrm{~min}^{-1}$ ) and the $\mathrm{GC}$ oven was heated using the following temperature program: $60^{\circ} \mathrm{C}$ for $1 \mathrm{~min}, 20^{\circ} \mathrm{Cmin}^{-1}$ to $150^{\circ} \mathrm{C}, 6^{\circ} \mathrm{Cmin}^{-1}$ to $320^{\circ} \mathrm{C}$ and a final hold time of $35 \mathrm{~min}$. Alkenones were identified by comparison of the retention times with a reference sample composed of known compounds. Peak areas were determined by integrating the respective peaks.

The $U_{37}^{K^{\prime}}$ index was calculated using the following equation (Prahl and Wakeham, 1987):

$$
U_{37}^{K^{\prime}}=\frac{\mathrm{C}_{37: 2}}{\mathrm{C}_{37: 2}+\mathrm{C}_{37: 3}}
$$

and converted to SST using the global surface water calibration from Conte et al. (2006):

$\mathrm{SST}=\frac{U_{37}^{K^{\prime}}-0.0709}{0.0322}$.

\subsection{Environmental physical parameters}

SST, sea surface temperature anomaly (SSTA), mixed layer depth (MLD) and upper ocean chlorophyll $a$ concentration data are based on satellite-derived data achieved from the NASA-supported Giovanni project (https://giovanni.gsfe. nasa.gov/, last access: 12 November 2019). SST is the mean of daily surface ocean temperature and MLD values of the sampling interval in a $4 \mathrm{~km}^{2}$ area around the trap position (Table 1). In the study area, SST at the mooring location is influenced by seasonal air temperature changes as well as the presence of upheld water surfacing at the trap position.

To compensate for seasonal air temperature changes, the SSTA is calculated by subtracting the above-calculated SST at the trap position from mean SST values of simultaneous sampling intervals in a $4 \mathrm{~km}^{2}$ block $200 \mathrm{nmi}$ west of the trap position. Both SSTA and MLD are parameters reflecting active upwelling in the study area. Upper-ocean chlorophyll $a$ data and MLD represent monthly mean values in a $9 \mathrm{~km}^{2}$ block around the trap position. Wind speed and wind directions are provided by Nouadhibou airport $\left(20^{\circ} 56^{\prime} \mathrm{N}, 17^{\circ} 2^{\prime} \mathrm{W}\right)$ (Institut Mauretanien de Recherches Océanographiques et des Pêches, Nouadhibou, Mauritania). For statistical analyses, the means of daily values during the trap sampling intervals were calculated. 


\subsection{Multivariate analyses}

To determine if a linear or unimodal-based ordination method should be applied to the data, we performed a detrended correspondence analysis before the statistical analysis. Results of this analysis revealed a total length of gradient of $1.2 \mathrm{sd}$, which indicates a linear species respond on environmental gradients. The ordination techniques principal component analysis (PCA) and redundancy analysis (RDA) have been accordingly performed. Significance of the environmental variables has been tested with a Monte Carlo permutation test with unrestricted permutations.

PCA and RDA have been performed with the software package Canoco 5 (ter Braak and Smilauer, 2012; Smilauer and Leps, 2014). To obtain insights into the temporal relationship between fluxes of organism groups (diatoms, coccolithophores, calcareous and organic-walled dinoflagellate cysts, planktonic foraminifera and pteropods) and bulk components as well as the environmental conditions in surface waters and low atmosphere, a RDA has been performed. RDA compares the total flux of organism groups with environmental parameters and $\mathrm{TOC}, \mathrm{BSi}, \mathrm{CaCO}_{3}$ and lithogenic fluxes (Table 2). Since the fluxes of the individual groups differ by several orders of magnitudes, it is essential to normalize their flux values prior to the statistical analysis in order to be able to determine temporal relationships of flux variability. As a consequence, the total flux of the organism groups has been normalized to values between 0 and 1000 before the analyses according to Eq. (1):

$n \mathrm{Fl}_{i}=\left(\mathrm{FL}_{i / y} / \mathrm{FL}_{i} \max \right) \times 1000 n$,

where $\mathrm{Fl}_{i}$ is normalized flux of species group $i, \mathrm{Fl}_{i / y}$ is flux of species group $i$ in sample $y$ and $\mathrm{FL}_{i}$ max is maximal flux observed in species group $i$.

To better understand the relationship within the individual organism groups, a PCA has been performed (Table 2). For these analyses, the total flux of the organisms or species groups have been normalized to values between 0 and 1000 according to Eq. (2):

$n \mathrm{Fl}_{i j}=\left(\mathrm{FL}_{i j / y} / \mathrm{FL}_{i j} \max \right) \times 1000 n$,

where $\mathrm{Fl}_{i j}$ is normalized accumulation rate of ecological entity $j$ in species group $i, \mathrm{Fl}_{i j / y}$ is accumulation rate of ecological entity $j$ in sample $y$ and $\mathrm{FL}_{i j}$ max is maximal accumulation rate observed in species group $i$.

Within coccolithophores, Umbilicosphaera anulus had exceptionally large fluxes in one sample only. This flux exceeded the maximal flux of the other species by a factor of 3 . This value has been excluded from the analysis and the $\mathrm{FL}_{j}$ max in this group is determined by excluding this outlier.

\section{Results}

\subsection{Bulk fluxes and fluxes of organism groups}

Independent of the year, the total mass flux of particulates at site CBeu is mainly composed of biogenic components (calcium carbonate, BSi and TOC; Table 3; Fischer et al., 2019). Calcium carbonate is the main bulk biogenic component. The daily average flux of $\mathrm{CaCO}_{3}-$ calculated for each full calendar year sampled between 2004 and 2007 - varies between 121.1 and $150.9 \mathrm{mg} \mathrm{m}^{-2} \mathrm{~d}^{-1}$ (Table 3). BSi is the second most important biogenic bulk component (35.8-54.61 mg m $\mathrm{m}^{-2} \mathrm{~d}^{-1}$, Table 3), followed by TOC $\left(19.00-29.40 \mathrm{mg} \mathrm{m}^{-2} \mathrm{~d}^{-1}\right)$. Lithogenic material is the main non-biogenic contributor to the total mass flux (84.6$134.2 \mathrm{mg} \mathrm{m}^{-2} \mathrm{~d}^{-1}$, Table 3). Coccolithophores, planktonic foraminifera, calcareous dinoflagellates and pteropods are the main contributors to the $\mathrm{CaCO}_{3}$ flux, while diatoms dominate the siliceous community.

The fluxes of total mass, $\mathrm{CaCO}_{3}$, TOC, BSi and lithogenic material show major peaks in winter and spring (Fig. 2). Secondary maxima were found during late summer/fall, mainly in 2003, and less clearly in 2005, 2006 and 2007 (Fig. 2). However, the individual components reveal different flux amplitudes and point to some interannual variability (Table 3 ). $\mathrm{CaCO}_{3}$ fluxes were exceptionally high in early winter 2005 compared to the other years. Fluxes of BSi and TOC match well the flux pattern of total mass and show less interannual variability (Fig. 2c, d). The flux of the lithogenic fraction has the highest amplitudes in spring 2006 and 2007 (Fig. 2e).

Fluxes of microorganisms are dominated by diatoms and coccoliths (Fig. 3a, b). These exceeded the fluxes of organic- and calcareous-walled dinoflagellate cysts, planktonic foraminifera and pteropods by a factor of 4 to 5 . Highest coccolithophore and diatom fluxes reach $4.2 \times$ $10^{9}$ coccoliths $\mathrm{m}^{-2} \mathrm{~d}^{-1}$ and $1.2 \times 10^{8}$ valves $\mathrm{m}^{-2} \mathrm{~d}^{-1}$, respectively. Maximal fluxes for organic-walled dinoflagellates reach up to $7.1 \times 10^{4}$ cysts m${ }^{-2} \mathrm{~d}^{-1}$, for planktonic foraminifera they reach $0.9 \times 10^{4}$ shells $\mathrm{m}^{-2} \mathrm{~d}^{-1}$ and for pteropods they reach $1.1 \times 10^{4}$ shells $\mathrm{m}^{-2} \mathrm{~d}^{-1}$.

Each group of microorganisms shows large seasonal and interannual variability (Table 5). Diatoms had their maximal flux in fall/winter 2005 and spring/summer 2006 (Fig. 3a). Coccolithophores had their highest fluxes mostly in winter/spring throughout the sampling interval and exceptionally in July/August 2003 and 2007 and in fall 2005. On the long-term, low coccolithophore fluxes were observed in fall and winter 2007/2008 (Fig. 3b). Calcareous dinoflagellate cysts were practically absent until fall 2005 (Fig. 3c). After September 2005, calcareous dinoflagellate cysts showed maximal export fluxes in fall/winter 2005/2006 and fall/winter 2006/2007 (Fig. 3c). Fluxes decreased again after spring 2007. Organic-walled dinoflagellate cysts had their highest export fluxes in summer 2003, spring/summer 2006 and summer 2007 (Fig. 3d). Planktonic foraminifera showed 


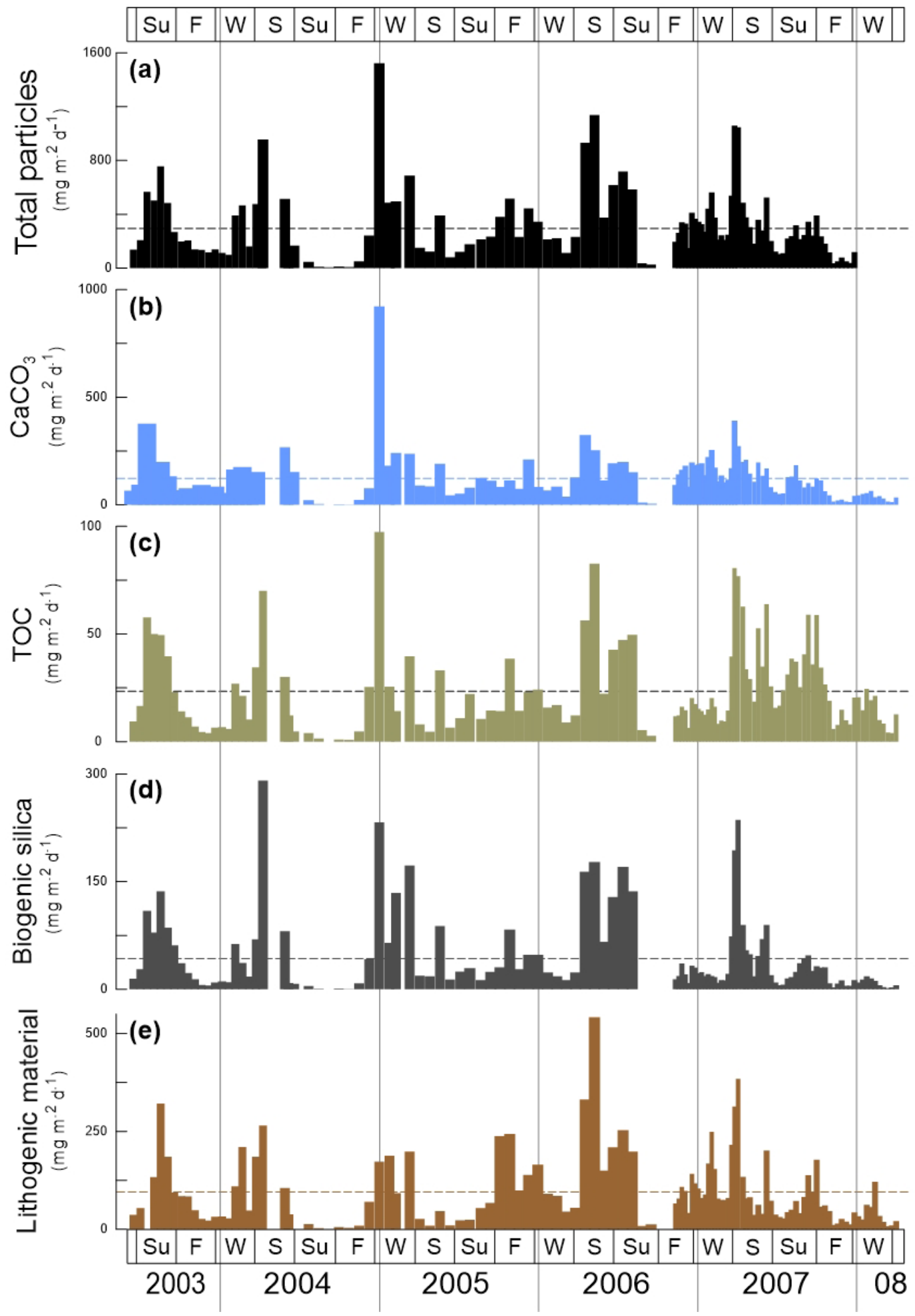

Figure 2. Total mass particle and bulk fluxes at the trap site CBeu between June 2003 and March 2008. From top to bottom: (a) total mass particle ( $\mathrm{mg} \mathrm{m}^{-2} \mathrm{~d}^{-1}$, black bars), (b) calcium carbonate $\left(\mathrm{CaCO}_{3}, \mathrm{mg} \mathrm{m}^{-2} \mathrm{~d}^{-1}\right.$, light blue bars), (c) total organic carbon (TOC, mg m ${ }^{-2} \mathrm{~d}^{-1}$, olive bars), (d) biogenic silica (BSi, opal, $\mathrm{mg} \mathrm{m}^{-2} \mathrm{~d}^{-1}$, dark gray bars), and (e) lithogenic material ( $\mathrm{mg} \mathrm{m}^{-2} \mathrm{~d}^{-1}$, brown bars). The horizontal stripped line for each parameter represents the average flux for the whole studied interval (Table 1). The boxes in the upper and lower panels represent seasons (Su: summer, F: fall, W: winter, S: spring). The vertical background gray lines indicate calendar year separation. For interpretation of the references to color in this figure legend, the reader is referred to the web version of this article. 


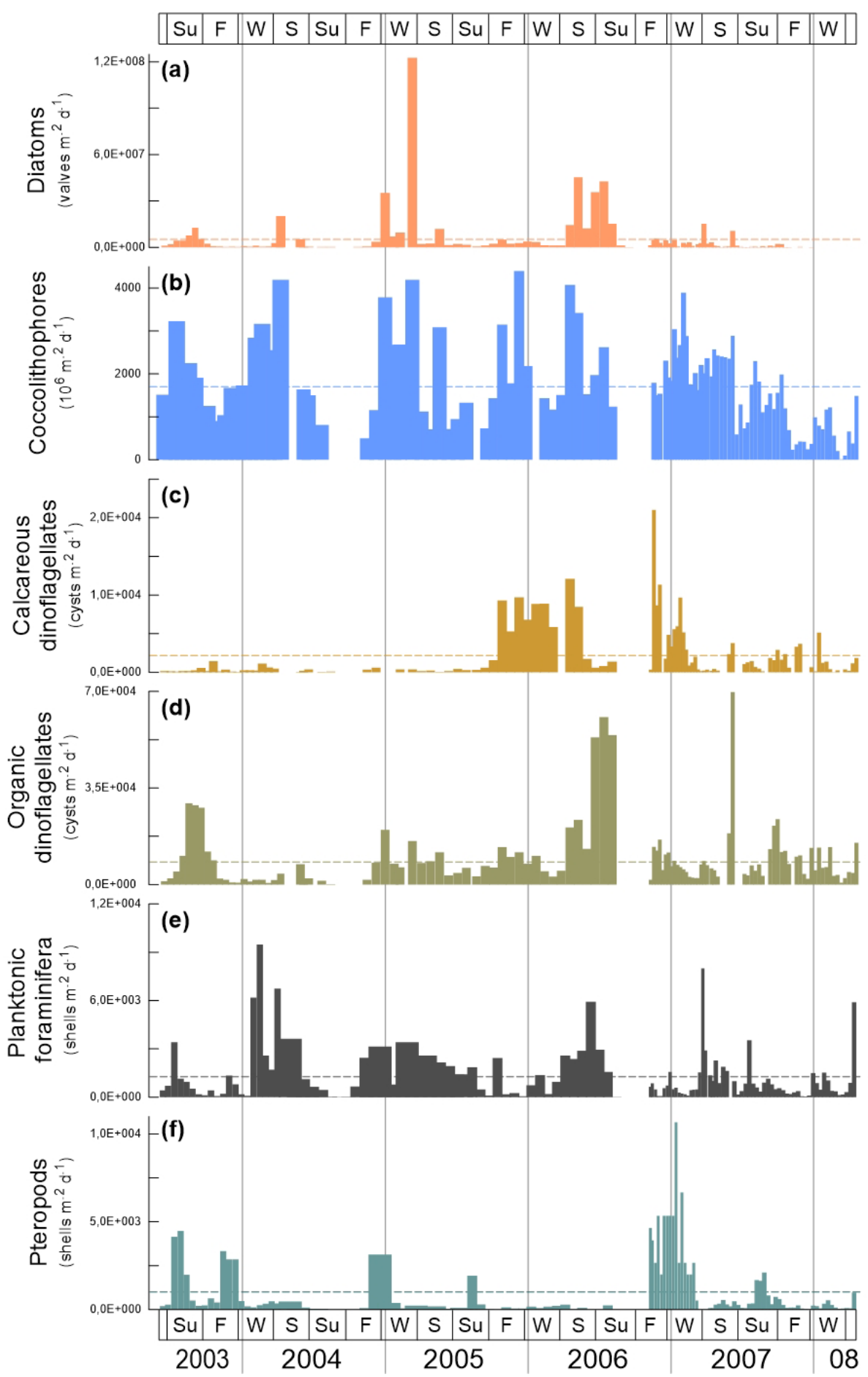

Figure 3. Fluxes of microorganisms at the trap site CBeu between June 2003 and March 2008. From top to bottom: (a) diatoms (valves $\mathrm{m}^{-2} \mathrm{~d}^{-1}$, peach bars; note that 10 samples corresponding to CBeu 5 - 13 December 2007 through 17 March 2008 - were not available for diatom analysis); (b) coccolithophores (coccoliths $\mathrm{m}^{-2} \mathrm{~d}^{-1}$, light blue bars); (c) calcareous dinoflagellates (cysts $\mathrm{m}^{-2} \mathrm{~d}^{-1}$; gold bars); (d) organic dinoflagellates (cysts $\mathrm{m}^{-2} \mathrm{~d}^{-1}$; khaki bars); (e) planktonic foraminifera (shells $\mathrm{m}^{-2} \mathrm{~d}^{-1}$; gray bars), and (f) pteropods (shells $\mathrm{m}^{-2} \mathrm{~d}^{-1}$; ocean green bars). The horizontal stripped line for each group of organisms represents the average flux for the whole study interval. The boxes in the upper and lower panels represent seasons (Su: summer, F: fall, W: winter, S: spring). The vertical background gray lines indicate calendar year separation. For interpretation of the references to color in this figure legend, the reader is referred to the web version of this article. 
Table 2. Main result values of the ordination techniques redundancy (RDA) and principal component (PCA) analyses performed with the software package Canoco 5 (ter Braak and Smilauer, 2012; Smilauer and Leps, 2014).

\begin{tabular}{|c|c|c|c|c|c|c|c|c|}
\hline Analysis & Method & Analyzed parameters & $\begin{array}{r}\text { Length of } \\
\text { gradient }\end{array}$ & $\begin{array}{r}\text { Eigenvalue } \\
\text { axis } 1(\%)\end{array}$ & $\begin{array}{l}\text { Eigenvalue } \\
\text { axis } 2(\%)\end{array}$ & $\begin{array}{r}\text { Eigenvalue } \\
\text { axis } 3(\%)\end{array}$ & $\begin{array}{r}\text { Eigenvalue } \\
\text { axis } 4(\%)\end{array}$ & $P$ value \\
\hline 1 & RDA & $\begin{array}{l}\text { Fluxes of microorgan- } \\
\text { isms and bulk parame- } \\
\text { ters, environmental pa- } \\
\text { rameters }\end{array}$ & 1.8 & 34.5 & 10.7 & 4.7 & 2.1 & 0.002 \\
\hline 2 & PCA & microorganisms & 1.4 & 26.3 & 16.2 & 9.8 & 6.9 & \\
\hline
\end{tabular}

References: RDA, redundancy analysis; PDA, principal component analysis.

Table 3. Average daily fluxes of total mass, calcium carbonate $\left(\mathrm{CaCO}_{3}\right)$, total organic carbon (TOC), biogenic silica and lithogenic material $\left(\mathrm{mg} \mathrm{m}^{-2} \mathrm{~d}^{-1}\right)$ calculated at site CBeu for full calendar years 2004, 2005, 2006 and 2007.

\begin{tabular}{|c|c|c|c|c|c|c|c|c|c|}
\hline \multirow[t]{2}{*}{ Year } & \multirow{2}{*}{$\begin{array}{r}\text { Total mass } \\
\left(\mathrm{mg} \mathrm{m}^{-2} \mathrm{~d}^{-1}\right)\end{array}$} & \multicolumn{2}{|l|}{$\mathrm{CaCO}_{3}$} & \multicolumn{2}{|l|}{ TOC } & \multicolumn{2}{|c|}{ Biogenic silica } & \multicolumn{2}{|c|}{ lithogenic material } \\
\hline & & $\left(\mathrm{mg} \mathrm{m}^{-2} \mathrm{~d}^{-1}\right)$ & $(\%)$ & $\left(\mathrm{mg} \mathrm{m}^{-2} \mathrm{~d}^{-1}\right)$ & $(\%)$ & $\left(\mathrm{mg} \mathrm{m}^{-2} \mathrm{~d}^{-1}\right)$ & $(\%)$ & $\left(\mathrm{mg} \mathrm{m}^{-2} \mathrm{~d}^{-1}\right)$ & $(\%)$ \\
\hline 2004 & $309.5+403.9$ & $150.9+360.2$ & 48.75 & $21.93+39.7$ & 7.15 & $54.61+85.6$ & 17.57 & $84.6+66.5$ & 27.33 \\
\hline 2005 & $317.5+176.6$ & $125.5+65.3$ & 39.45 & $19.00+11.00$ & 6.00 & $52.4+46.2$ & 16.50 & $101.7+82.5$ & 32.03 \\
\hline 2006 & $377.9+281.9$ & $142.8+79.1$ & 37.79 & $23.3+20.6$ & 6.19 & $54.07+60.2$ & 14.31 & $134.2+122.6$ & 35.51 \\
\hline 2007 & $282.8+225.1$ & $121.1+80.2$ & 42.18 & $29.4+19.6$ & 10.38 & $35.8+46.9$ & 12.66 & $92.9+83.4$ & 32.85 \\
\hline
\end{tabular}

maximal fluxes in summer 2003; winter/spring 2004, 2005, and 2007; and spring/summer 2006 (Fig. 3e). Pteropods had their maximal fluxes in summer 2003; fall/winter 2003/2004, 2004/2005, and 2006/2007; and summer 2005 and 2007 (Fig. 3f).

\subsection{Species- and group-specific compositions of assemblages}

The studied plankton community at the CBeu site is highly diverse and is composed by at least 220 identified species. Table 5 presents the species-specific composition of groups depicted in Fig. 4.

Out of 170 marine diatom species, the 70 most abundant diatom taxa (average relative contribution $>0.75 \%$ for the entire studied interval) were attributed to four groups, according to the main ecological conditions they represent: (1) benthic, (2) coastal upwelling, (3) coastal planktonic and (4) open-ocean waters (see also Romero and Fischer, 2017). The diatom groups show a clear seasonal pattern and strong interannual variability (Fig. 4a, Table 4). Benthic diatoms have higher relative contributions during spring and summer, whereas the coastal upwelling group mainly occurred between late spring and early fall. Open-ocean diatoms were more abundant from fall to early spring, while the coastal planktonic taxa tended to be more abundant during fall and winter. Most noticeably, a drastic shift in the relative contribution of the benthic diatoms occurred in spring/summer 2006 when the abundance of benthic diatoms strongly increased from 2006 onward, compared to 2003-
2005 (Fig. 4a, Table 4). In spite of the increased relative contribution of benthic diatoms after 2005, the seasonal pattern of the predominantly high spring/summer total diatom flux remained unaltered (Fig. 3a).

Coccolithophores are consistently dominated by Emiliania huxleyi and Gephyrocapsa oceanica, whose combined contribution always represents $>50 \%$ of the community throughout the sampling period (Fig. 4b, Table 4). Oligotrophic upper photic zone (UPZ, e.g., Umbellosphaera tenuis, $U$. irregularis) and lower photic zone species (LPZ, e.g., Florisphaera profunda, Gladiolithus flabellatus) make up the majority of the remaining species. Whereas $E$. huxleyi showed a less clear seasonal pattern, G. oceanica tends to be more abundant during late spring and early fall (Fig. 4b). In contrast, UPZ and LPZ taxa have higher relative contributions during winter and spring. The appearance of Umbilicosphaera anulus (present in consistently low relative abundances of 5\%-10\% until the summer of 2006) accounts for up to $65 \%$ of the community in winter $2005 / 2006$. Other common taxa with an average relative contribution $>0.75 \%$ for the entire studied interval are listed in Table 5.

Calcareous dinoflagellate cysts can be attributed to five groups according to the main ecological conditions they represent (Siggelkow et al., 2002; Richter et al., 2007; Kohn and Zonneveld, 2010): (1) upwelling, (2) warm waters, (3) terrestrial mineral input, (4) cosmopolitan and (5) other species (Table 5). Until fall 2005 abundances are very low such that the recognition of a seasonal pattern is hampered (Fig. 4c). After fall 2005, their occurrence shows a clearer seasonal pattern. In spring/summer of 2006, upwelling species domi- 


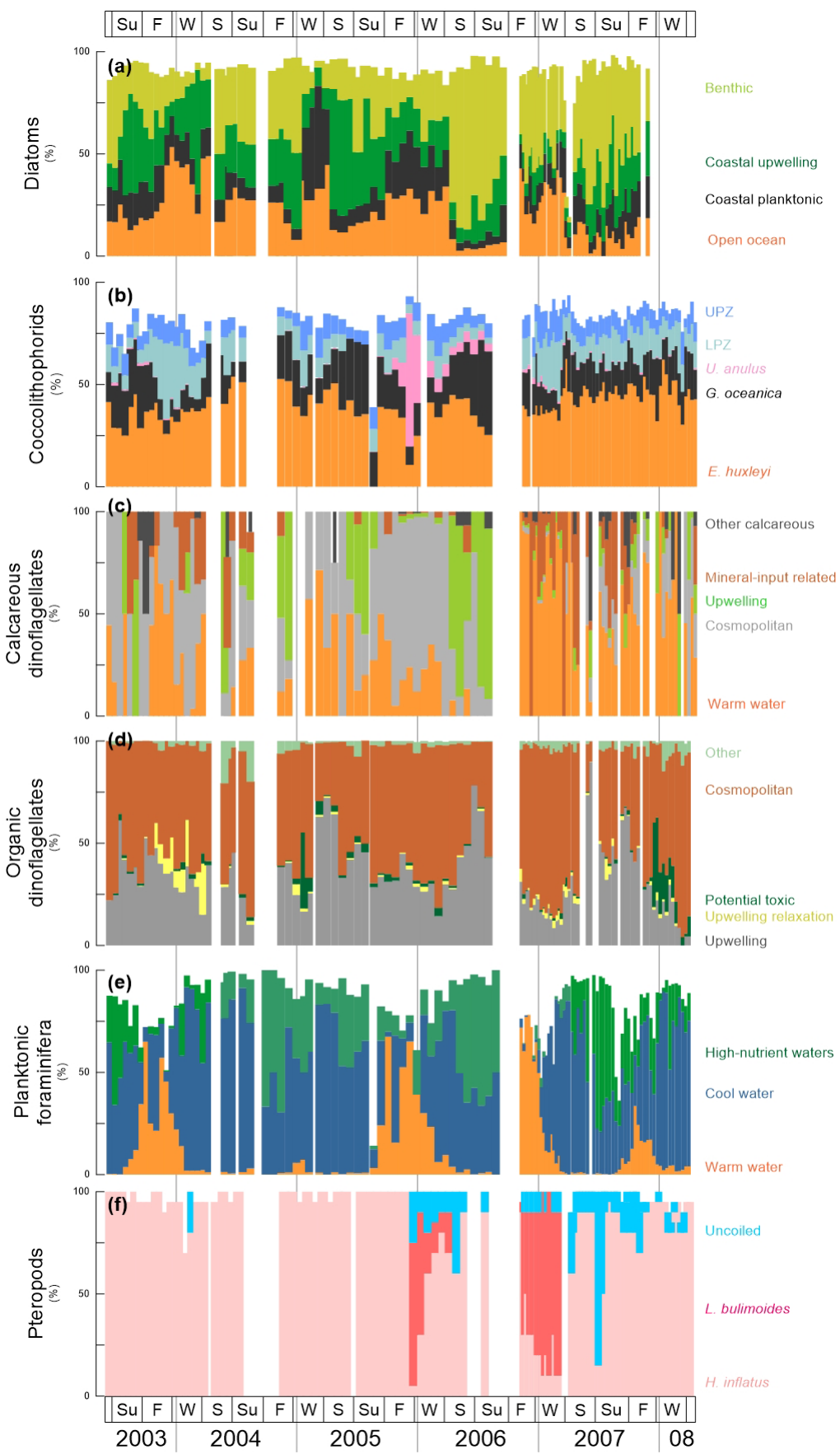

Figure 4. Cumulative relative abundance (\%) of main species or group of species of diatoms, coccolithophores, dinoflagellates, planktonic foraminifera and pteropods at the trap site CBeu between June 2003 and March 2008 (Table 1). From top to bottom: (a) diatoms - benthic, light green bars; coastal upwelling, dark green bars; coastal planktonic, black bars; and open ocean (\%, orange bars; note that 10 samples corresponding to CBeu 5 - 13 December 2007 through 17 March 2008 - were not available for diatom analysis); (b) coccolithophores - upper photic zone, blue bars; lower photic zone, moss green; Umbilicosphaera anulus, pink bars; Gephyrocapsa oceanica, black bars; Emiliania huxleyi, orange bars; (c) calcareous dinoflagellates - other calcareous, dark gray bars; mineral-input related, brown bars; upwelling, light green bars; cosmopolitan, light gray; warm water, orange bars; (d) organic dinoflagellates - upwelling species (gray bars); upwelling relaxation species (light yellow bars); potential toxic (dark green bars); cosmopolitan, red brown bars; other, faded green bars; (e) planktic foraminifera - high nutrient water, green bars; cool water, blue bars; warm water, orange bars; and (f) pteropods - uncoiled species, light blue bars; Limacina bulimoides, red bars; Heliconoides inflatus, pink bars. Note that the relative contribution of diatoms, coccolithophores and planktonic foraminifera does not add up to $100 \%$ since the ecology of some taxa of these groups is not well constrained. The species-specific composition of groups is presented in Table 5. The boxes in the upper and lower panels represent seasons (Su: summer, F: fall, W: winter, S: spring). The vertical background gray lines indicate calendar year separation. For interpretation of the references to color in this figure legend, the reader is referred to the web version of this article. 


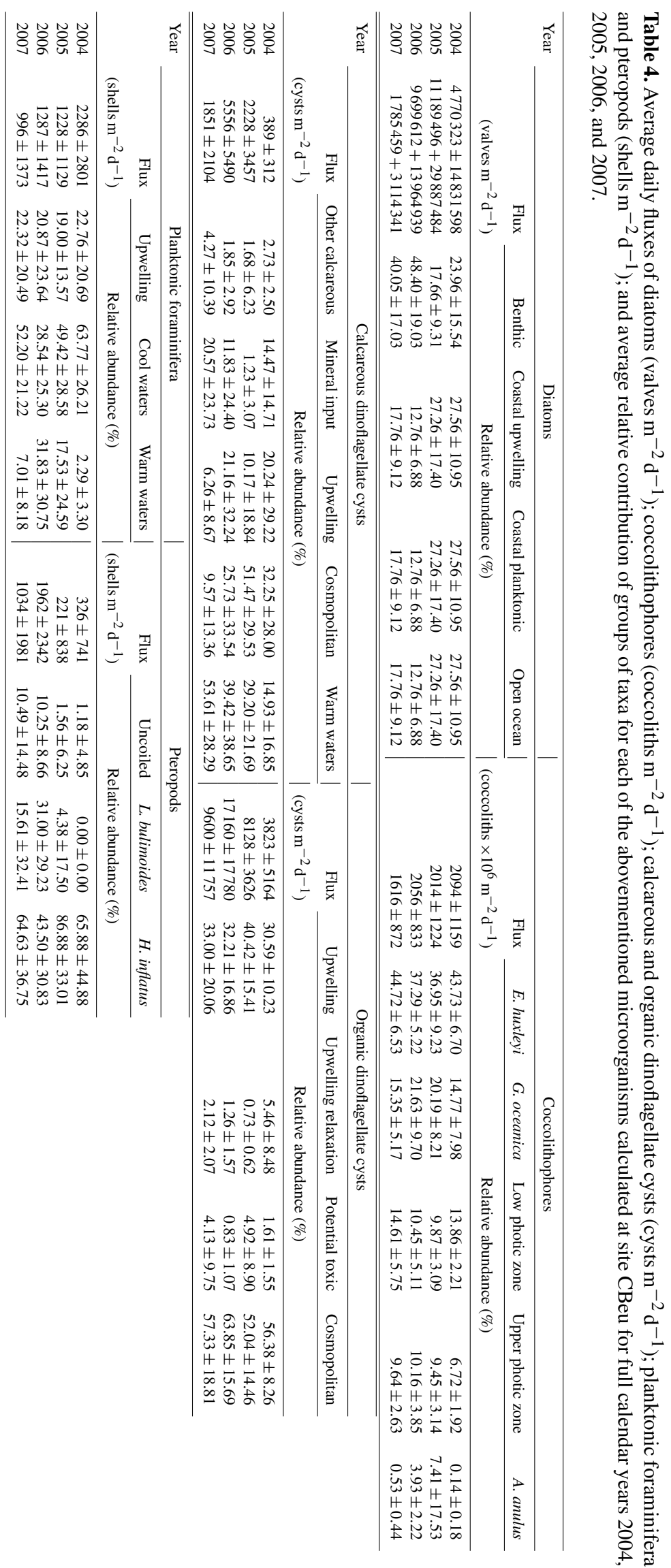


nate the association. After fall 2006, the community is composed through the interplay of cosmopolitan species, warmwater taxa and upwelling-dependent species, where warmwater taxa dominate. Whereas upwelling species are most abundant in spring and fall, warm-water and mineral indicators are more abundant in fall/winter (Fig. 4).

Organic dinoflagellate cysts can be attributed to five groups based on the relationship between their geographic distribution in surface sediments from the Cap Blanc area and the environmental conditions in surface and subsurface waters as well as long-term surveys of their seasonal cyst production (Susek et al., 2005; Holzwarth et al., 2010; Smayda, 2010; Smayda and Trainer, 2010; Trainer et al., 2010; Zonneveld et al., 2012, 2013): (1) upwelling, (2) upwelling relaxation, (3) potential toxic, (4) cosmopolitan and (5) other species. Throughout the investigated time interval, upwelling species are abundant in spring and fall/winter, whereas upwelling relaxation species have higher relative abundances in fall (Fig. 4d). Potential toxic species are abundant in fall/winter 2004/2005 and 2007/2008. Organic-walled dinoflagellate cysts do not show a clear change in their composition between 2005 and early 2006 (Table 4) as observed for many other groups.

The distribution and abundance of planktonic foraminifera species are linked to surface-water properties. We use prominent species as tracers of surface water properties: Globigerina bulloides, usually thriving in temperate to subpolar waters during intervals of enhanced primary productivity due to high nutrient availability (Schiebel and Hemleben, 2017), is generally most abundant between summer and fall (Fig. 4e). Transitional and subpolar species Globorotalia inflata and Neogloboquadrina incompta are usually present throughout a year, only decreasing in abundance in fall and winter when warm-water taxa peaked (Globigerinoides ruber pink, G. ruber white and G. sacculifer; Kucera, 2007; Schiebel and Hemleben, 2017) (Fig. 4e). The only exception is in fall and winter 2004/2005 when warm-water taxa are almost absent.

As large secondary carbonate producers off Mauritania, pteropods are important contributors to the carbonate flux in the CC-EBUE (Fischer et al., 2016). The community is composed of relatively few taxa. Heliconoides inflatus dominates the assemblage throughout most of the studied interval (Fig. 4f). It is often the only species found in the assemblage until winter 2005/2006, when a sudden and drastic shift in the relative contribution occurred. Limacina bulimoides appears for the first time in winter to spring 2006 - and again in fall and winter 2006/2007 - and dominates the assemblage together with a group of unspecified uncoiled pteropods. However, another occurrence of $L$. bulimoides is missing in winter $2007 / 2008$.

\subsection{Statistical analyses}

Comparison of the fluxes of the microorganisms, bulk components and the environmental conditions in surface wa-

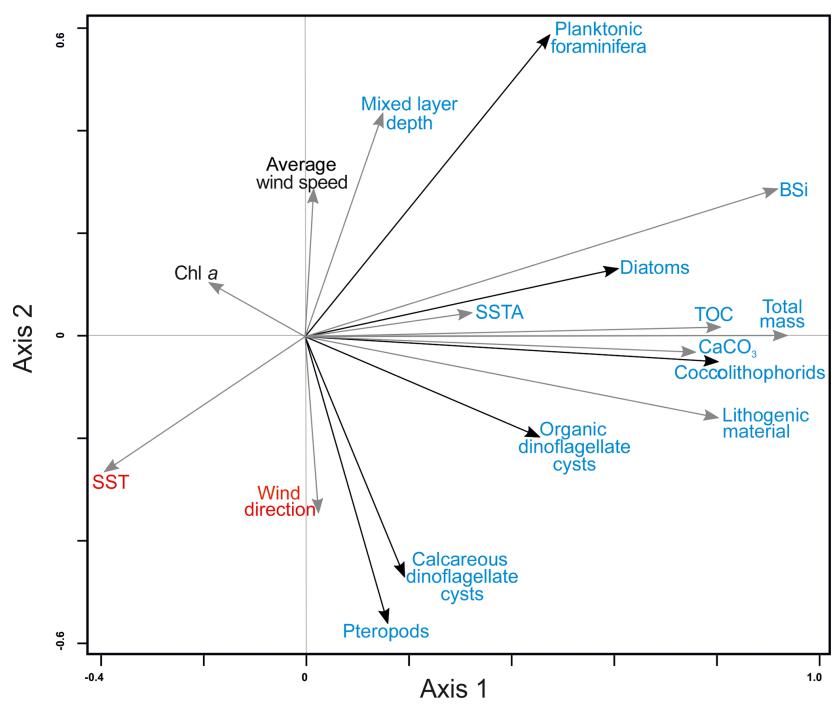

Figure 5. RDA ordination diagram depicting the relationship between the accumulation rates of organism groups and bulk fluxes and environmental conditions in upper waters. References are given as follows. Av. wind speed: average wind speed; Chl $a$ : chlorophyll $a$; TOC: total organic carbon; $\mathrm{CaCO}_{3}$ : calcium carbonate; MLD: mixed layer depth; SST: sea surface temperature; SSTA: sea surface temperature anomalies. For interpretation of the references to color in this figure legend, the reader is referred to the web version of this article.

ters and the lower atmosphere (MLD, average wind speed, wind direction, chlorophyll $a$ concentration (Chl $a$ ), SST and SSTA) resulted in a significant relationship within the first and second RDA axes that correspond to $34 \%$ and $11 \%$ of the variance within the dataset, respectively (Table 2 ).

All microorganism groups are ordinated on the positive part of the first axis showing a positive relationship with all bulk parameters (Fig. 5). This implies that the fluxes of total mass, TOC, BSi and $\mathrm{CaCO}_{3}$ increased with increasing fluxes of all studied microorganism groups (Fig. 5, Tables 3 and 4). Fluxes of planktonic foraminifera, diatoms, and to a lesser extent - coccolithophores and organic dinoflagellate cysts are ordinated on the negative side of SST and, with the exception of organic dinoflagellate cysts, ordinated on the positive side of MLD (Fig. 5). This implies that their fluxes are enhanced whenever SST is low and MLD is deep, i.e., under a well-mixed uppermost water column. Diatoms, coccolithophores, organic dinoflagellate cysts and planktonic foraminifera also show a positive correlation with SSTA, implying that enhanced fluxes of these microorganisms occur when temperature anomalies between waters overlying site CBeu and the offshore pelagial area is large. The flux of pteropods and calcareous dinoflagellate cysts are positively related to the average wind direction and negatively to MLD and average wind speed (Fig. 5).

Interestingly, the satellite-derived $\mathrm{Chl} a$ data do not show a significant correlation with fluxes of major microorgan- 
ism groups studied at site CBeu. This possibly indicates that (1) a large portion of satellite-measured chlorophyll concentration is delivered by microorganisms, which did not reach the CBeu trap, and/or (2), due to the strong ballasting effect, part of the microorganisms' remains reach the trap cups independent of intervals of highest satellite chlorophyll values. An alternative explanation is that (3) satellites measure the chlorophyll concentration in the uppermost centimeters of the water column, while microorganisms collected with the CBeu traps thrive mostly in waters deeper than those reached by satellite sensors.

To better understand the correlation of the fluxes of the species groups within the microorganism groups, PCA has been performed (Fig. 6, Table 2). The first two axes correspond to $26.3 \%$ and $16.2 \%$ of the variance within the dataset, respectively. Based on their ordination on the first and second axes, three groups are recognized (Fig. 6):

- Groups 1 and 2 are ordinated at the negative side of the second axis. Group 1 (in blue, Fig. 6) is built by planktonic foraminifera characteristic of cooler or highnutrient water masses (For-cold, For-hinut), benthic and upwelling-related diatoms (Dia-bent and Dia-upw), organic dinoflagellates characteristic of upwelling regions (OD-upw), and the coccolithophore Gephyrocapsa oceanica (Co-Gocean). Group 2 (in brown, Fig. 6) consists of upwelling-related and other calcareous dinoflagellates cysts (CD-upw and CD-other), other coccolithophores (Co-other), and coastal planktonic and open-ocean diatoms (Dia-coast and Dia-ocean).

- Ordinated on the positive side of the second axis and central part of the first axis, group 3 assembles planktonic foraminifera mainly thriving in warm waters (For-warm), calcareous dinoflagellates characteristic of warm-water conditions and those responding to mineral input (CD-warm, CD-min), as well as all pteropods taxa (in black, Fig. 6).

- Group 4 is ordinated at the central and positive parts of the second axis and positive side of the first axis. Species assigned to group 4 are organic-walled dinoflagellate cysts typical of the upwelling relaxation (OD-upw relax); UPZ and LPZ coccolithophores (Co-up phot and Co-low phot); and E. huxleyi (CoEhux), other coccolithophores (Co-other), U. anulus (Co-Uanu), and cosmopolitan calcareous dinoflagellate cysts (CD-cosm) (in red, Fig. 6).

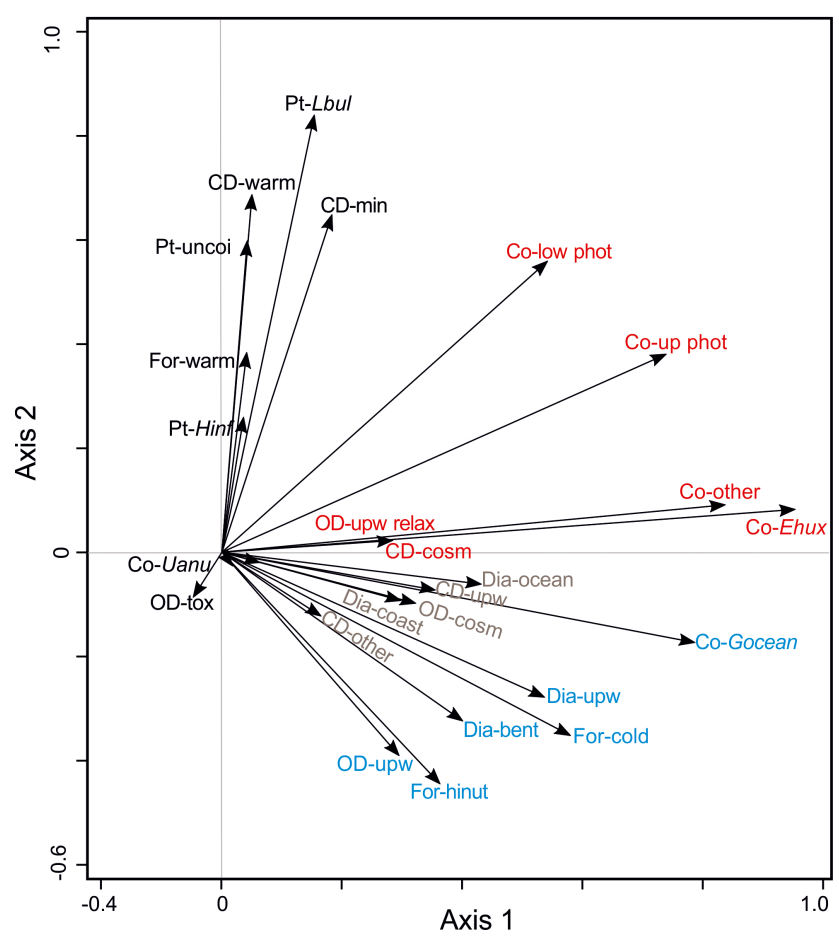

Figure 6. Results of a PCA analysis of ecological groups of the organism groups at the CBeu trap site between June 2003 and March 2008. References are given as follows. Dia (diatoms); -bent: benthic, -coast: coastal planktonic, -ocean: open ocean, -upw: upwelling; Co (coccolithophores); -Ehux: Emiliania huxleyi,-Gocean: Gephyrocapsa oceanica, -low phot: lower photic zone, -other: other coccolithophorids, -Uanu: Umbilicosphaera anulus, -up phot: upper photic zone; CD (calcareous dinoflagellate cysts); -cosm: cosmopolitan group, -min: terrestrial mineral group, -other: species that do not fit in one of the other ecological groups, -upw: upwelling, warm: warm waters; OD (organic-walled dinoflagellate cysts); -cosm: cosmopolitan group, -other: species that do not fit in one of the other ecological groups, -tox: potential toxic group, -upw: upwelling, -upw relax: upwelling relaxation; For (planktonic foraminifera); -cold: cool water group, -hinut: high-nutrient waters group; -warm: warm-water group; and Pt (pteropods); -Hinf: $\mathrm{He}$ liconoides inflatus, -Lbul: Limacina bulimoides, -uncoi: uncoiled. Groups of microorganisms are identified by colors (light blue, group 1; brown, group 2; black, group 3; and red, group 4). The species-specific composition of groups is presented in Table 5. For interpretation of the references to color in this figure legend, the reader is referred to the web version of this article.

\section{Discussion}

\subsection{Relationship between microorganism fluxes at site CBeu and the physical and biogeochemical settings off Mauritania}

Both the visual examination of the flux variability and the performed statistical analysis provide evidence to show that the seasonality of most microorganism groups at the CBeu site closely follows the temporal pattern of changes 


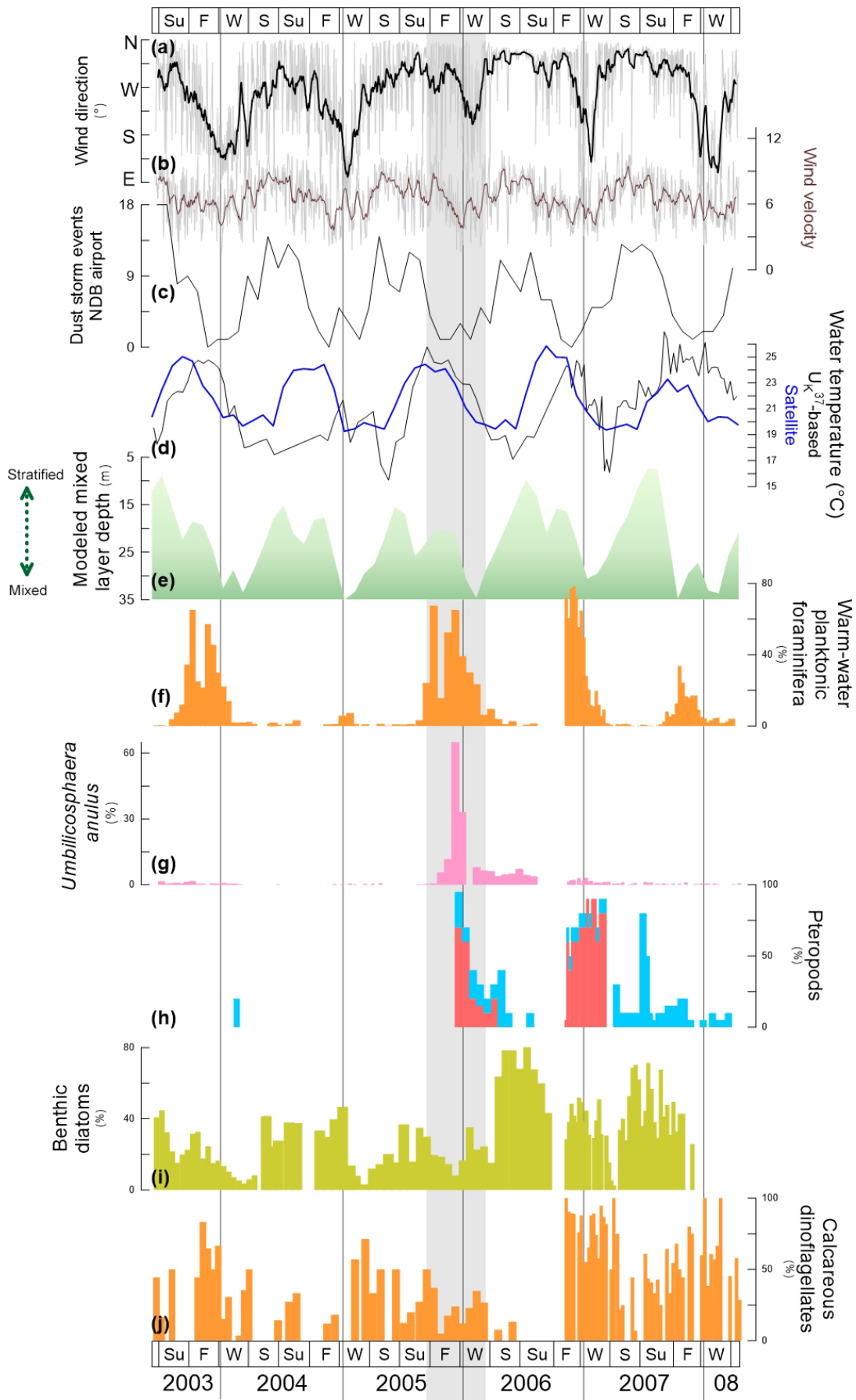

Figure 7. Comparison of physical data (a-e) and relative abundance of selected species or group(s) of species (f-j) at site CBeu between June 2003 and March 2008. Physical data: (a) origin of daily wind direction (the gray line are daily data, the thicker black line represent the 17-running point average); (b) daily wind velocity $\left(\mathrm{m} \mathrm{s}^{-1}\right.$, the gray line are daily data, the thicker dark brown line represent the 17-running point average), (c) dust storm event (number of events) recorded at the meteorological station of the airport of Nouadhibou (ca. $20^{\circ} 57^{\prime} \mathrm{N}$, $17^{\circ} 02^{\prime} \mathrm{W}$, Mauritania); (d) seawater temperature $\left({ }^{\circ} \mathrm{C}\right): U_{37}^{K^{\prime}}$-based reconstruction (black line) and satellite-imagery-generated data (blue line); (e) mixed layer depth (m, gray line, https://modis.gsfc.nasa.gov, last access: 12 November 2019 for the area between $19-18^{\circ} \mathrm{W}$ and 20-2 $21^{\circ} \mathrm{N}$ ). Relative contribution (\%) of (f) warm-water planktonic foraminifera (orange bars); (g) the coccolithophore $U$. anulus (pink bars); (h) pteropods L. bulimoides (red bars) and uncoiled species (light blue bars); (i) benthic diatoms (banana yellow bars); and (j) calcareous dinoflagellates (light orange bars). The species-specific composition of groups is presented in Table 5. The vertical gray lines indicate years separation. The light gray shading in the background highlights the interval of main shift in flux values and/or the relative contribution of particular species or groups of species (see discussion in Sect. 5.3.). For interpretation of the references to color in this figure legend, the reader is referred to the web version of this article. 
in upper-water oceanographic conditions off Mauritania between June 2003 and March 2008. Fluxes of diatoms, coccolithophores, organic-walled dinoflagellate cysts and planktonic foraminifera increase whenever the uppermost water column is well mixed (Fig. 7e), SSTs are low (Fig. 7d) and SSTA is high (Figs. 2, 3, 5). This strong match supports the scenario of simultaneous occurrence of intense upwelling off Mauritania and high microorganism fluxes at site CBeu. Several previous studies have separately documented enhanced production of diatoms, coccolithophores, organicwalled dinoflagellate cysts and planktonic foraminifera occurring when the nutrient concentration in the uppermost water column off Mauritania increases (Baumann et al., 2005; Zonneveld et al., 2012; Guerreiro et al., 2017; Romero and Fischer, 2017; Pospelova et al., 2018).

The atmospheric, hydrographic and biochemical conditions deliver the physical parameters and nutrient conditions that determine the temporal pattern of population dynamics as recorded by the CBeu trap. Wind and upper-water conditions off Mauritania show a clear seasonal pattern of variability (Fig. 7a-e). The highly stratified uppermost water column (above $40 \mathrm{~m}$ water depth) overlying site CBeu is an effect of winds blowing mainly from the N-NE between late winter and early summer (Fig. 7a, b, e). The stratification off Mauritania breaks down mostly in early to middle winter when the predominant winds turn from N-NE to S-SE (Fig. 7a). Following this setting, upwelling reaches its highest intensity between late winter to early spring and early summer (Mittelstaedt, 1991; Meunier et al., 2012; Cropper et al., 2014). The SST record (Fig. 7d) matches well the seasonal alternation of stratification and mixing conditions: lowest temperatures occur mostly between winter and early spring (increasing SSTA in late winter and throughout spring). Throughout the period investigated, this SST cyclicity remains fairly constant.

Fluxes of total mass and biogenic bulk components $\left(\mathrm{CaCO}_{3}, \mathrm{BSi}, \mathrm{TOC}\right)$ are clearly seasonal in nature (Fig. 3ad; Fischer et al., 2019) and reflect the temporal productivity pattern of the Mauritanian upwelling region (Meunier et al., 2012; Cropper et al., 2014). The good temporal match between flux maxima of most of the studied microorganism groups and biogenic bulk components unambiguously provides evidence to show that the contribution of primary and secondary producers to the total mass/biogenic mass fluxes off Mauritania (Figs. 2, 3). Higher absolute values of $\mathrm{CaCO}_{3}$ over $\mathrm{BSi}$ (Fig. 2b, d, Table 3) support the scenario of calcareous primary and secondary producers (coccolithophores, planktonic foraminifera and pteropods) dominating the plankton community in the Mauritanian upwelling system (Fischer et al., 2019). Diatoms are the main contributors to the BSi flux (Figs. 3a, 2d; Romero et al., 2002; Romero and Fischer, 2017).

A strong match among fluxes of diatoms, coccolithophores, organic-walled dinoflagellate cysts and planktonic foraminifera with lithogenic fluxes at times of intense upwelling is observed (Figs. 2e, 3a-c, e). The RDA sup- ports this correlation (Fig. 5). The good correlation between lithogenic and microorganism fluxes demonstrates that winds - responsible for the water column mixing off Mauritania (Mittelstaedt, 1983; Meunier et al., 2012) - might additionally enrich surface waters overlying site CBeu with landderived nutrients. Primary and secondary producers may remarkably benefit from this eolian-transported pool of nutrients. Lithogenic material is brought into Mauritanian ocean waters in the form of dust that is transported from the Sahara and the Sahel (Romero et al., 2003; Friese et al., 2017). Numerous studies have thoroughly documented that the particle flux off Mauritania predominantly occurs in the form of aggregates, often rich in lithogenic particles (e.g., Karakaş et al., 2009; Iversen et al., 2010; Iversen and Ploug, 2010; Nowald et al., 2014; Fischer et al., 2016; van der Jagt et al., 2018). Recent experiments have also shown that aggregate abundances and sinking velocities increase toward deeper waters when aggregates are ballasted with lithogenic particles, whereas aggregates are not able to scavenge lithogenic material from deeper waters (van der Jagt et al., 2018). Further evidence of a possible ballasting effect on the flux of bulk components was recently presented by Fischer et al. (2019). These authors observed that individual high BSi maxima at site CBeu revealed a peak-to-peak correlation with the dust fluxes. This was interpreted to indicate a strong coupling between dust deposition (lithogenic flux) and the efficiency of the biological pump under dry depositional conditions in winter off Mauritania. Based on these observations, Fischer et al. (2019) proposed that the ballasted organic-rich aggregates built in surface waters immediately react to any additional dust supply with aggregation followed by rapid sedimentation. Experimental studies on aggregate ballasting and scavenging off Mauritania (van der Jagt et al., 2018) support this view as well.

A remarkable finding of our multiannual trap experiment is that flux maxima of diatoms, coccolithophores, organicwalled cysts producing dinoflagellates (all primary producers) and planktonic foraminifera (secondary producers) seem to occur fairly simultaneously (Figs. 3, 5). We propose three possible interpretations: (i) no clear short-term succession of the microorganism groups occurred (no temporal turnover in phytoplankton composition within a few days; Roelke and Spatharis, 2015), (ii) the succession is not properly captured due to low temporal resolution of some sediment trap intervals (Table 1) and/or (iii) the microorganisms - originally produced in surface and subsurface waters by different communities - sink with different velocities through the water column toward the ocean bottom and get mixed during their sinking, mainly due to dissimilar weights and sizes of their remains.

Although it is widely believed that the supply of resources regulates the marine community structure (Roelke and Spatharis, 2015), experimental data show that the competition of resources per se does not lead to succession of phytoplankton populations. For instance, Barber and His- 
cock (2006) observed that marine picoplankton is not replaced by diatoms when chemical transient conditions (e.g., added iron) abruptly provide a more favorable growth setting. The enormous proportional increase in diatom biomass has fostered the misconception that diatoms replace the nondiatom taxa by succession as the bloom matures. Additional evidence is provided by observational studies. Bringué et al. (2018) observed that autotrophic dinoflagellates in the Cariaco Basin do not appear to compete with diatoms for resources as both groups respond positively to upwelling dynamics. Similarly, Anabalón et al. (2014) observed equal and simultaneous contributions of diatoms and pigmented dinoflagellates to total autotrophic biomass off Cap Ghir located in the northern CC-EBUEs. Contrary to conventional wisdom, Anabalón et al. (2014) demonstrate that groups of phytoplankton increase in growth rates and absolute abundance, but the biomass increase in the ambient non-diatom assemblage is modest, especially compared to the order of magnitude or more increase in diatom biomass.

The first three CBeu trap experiments had long lowresolution sampling intervals ( $>18 \mathrm{~d}$ per sample, June 2003 through September 2006, Table 1). However, the highresolution intervals of CBeu deployments 4 and 5 (up to 7.5 d per sample, October 2006-March 2008, Table 1) should have captured a possible short-term succession of major groups (e.g., diatoms quickly reacting to increasing nutrient availability, whereas photosynthetic dinoflagellates becoming more abundant during upwelling relaxation; Margalef, 1963; Jiménez-Quiroz et al., 2019). Although we do not dismiss the possible occurrence of succession within studied populations at site $\mathrm{CBeu}$, at this stage we also do not disregard its occurrence. It should also be kept in mind that the deployed traps capture those microorganism remains that reach the trap cups at around $1300 \mathrm{~m}$ water depth, while they hardly capture green algae or cyanobacteria thriving in surface waters. CBeu traps at ca. $1300 \mathrm{~m}$ water depth capture a mixed signal of sinking particles from a surface catchment area of at least ca. $100 \mathrm{~km}^{2}$ (Siegel and Deuser, 1997; Fischer et al., 2016) due to (i) differential settling velocities of particles (Fischer and Karakaş, 2009; Iversen et al., 2010; van der Jagt et al., 2018) and (ii) highly heterogeneous and dynamic surface water conditions due to filament and eddy activity off Mauritania (Mittelstaedt, 1991; Gabric et al., 1993; Meunier et al., 2012; Cropper et al., 2014). Additionally, the trapped signal is always affected by dissolution of particular species and groups of organisms sinking through the water column into deeper waters (e.g., Romero et al., 1999, 2002).

\subsection{Temporal variations of the species-specific composition of the plankton community}

We are aware that $1900 \mathrm{~d}$ of continuous sampling cannot deliver a definite picture of all temporal changes affecting the composition of the plankton community in the very dynamic Mauritanian upwelling. However, the overall tempo- ral pattern observed led us to propose a general sequence of seasonal variability. Most of the major microorganism groups occur simultaneously and clear successional trends are not quite distinguishable (Fig. 3). Despite strong interannual variability (Table 4), a consistent seasonal pattern in the occurrence of species or groups of species can still be recognized. Figure 4 shows the seasonal evolution of populations responding to the temporal dynamics of nutrient availability, e.g., following short-period dust events (Fig. 2e) and/or vertical mixing events associated with stronger winds (Fig. 7a, e). Based on the visual data examination and the statistical analysis, four groups of species are recognized (Figs. 3, 6). Populations of group 1 (Dia-bent, Dia-upw, Co-Gocean, ODupw, For-cold is in blue in Fig. 6) have higher relative contribution during the most intense phase of the upwelling season (mainly between late winter/early spring and early summer; Mittelstaedt, 1983; Cropper et al., 2014). Group 1 quickly responds to intense mixing and lowered SST at the CBeu site (Fig. 7d, e) and represents the typical upwelling-related association off Mauritania. This observation confirms the ecological characterization of the species groups that has been separately presented in previous biogeographical and ecological studies (Romero et al., 2002; Kucera, 2007; Köbrich and Baumann, 2008; Köbrich et al., 2016; Zonneveld et al., 2013; Romero and Fischer, 2017).

Diatoms of coastal regions (Dia-coast, non-upwelling related) and those thriving in open-ocean waters (Dia-ocean) together with other calcareous dinoflagellates (CD-other), cosmopolitan organic dinoflagellate cysts (OD-cosm) and "other coccolithophores" (Co-other) are assigned to group 2 (in brown in Fig. 6). Except for the cosmopolitan organic dinoflagellate cysts, all components of group 2 are primary producers and occur more abundantly between early fall and late winter (Fig. 4), at times of deepening of the mixed layer and upwelling relaxation (Fig. 7e). Group 2 represents a primary producer signal typical of meso- to oligotrophic water conditions off Mauritania, occurring under weakened upwelling, when winds predominantly blow from the N-NE, SSTs start decreasing after their summer peak and the uppermost water column stratifies (Fig. 7a, d, e).

Except for warm waters (CD-warm) and dust inputsensitive (CD-min) calcareous dinoflagellate cysts, group 3 is mainly composed of secondary producers: warm-water planktonic foraminifera and all pteropods (Fig. 4e, f). As such, this group represents the calcareous fraction of zooplankton feeding on (primary) phytoplankton, occurring mainly during phases of predominantly warmer SSTs (Fig. 7d), N-NE-originated winds (Fig. 7a) and a stratified uppermost water column (Fig. 7e). SST appears to be the most important factor controlling assemblage composition of planktonic foraminifera (Kucera, 2007). Large symbiont-bearing specialists like G. ruber and G. sacculifer are adapted to more oligotrophic and warmer waters. They show their maximum abundance in warm waters with a deeper mixed-layer depth (Fig. 7e, f). 
The seasonal dynamics of group 4 is similar to that of group 3 (intervals of weakened upwelling conditions), but they differ in their composition: group 4 is mainly made of calcareous primary producers. These populations dominate the plankton community during intervals of weakened upwelling, shallow MLD and predominantly oligotrophic water conditions. Similar to group 3, group 4 consists mainly of coccolithophores (the dominant E. huxleyi, accompanied by UPZ and LPZ, U. anulus, Figs. 4b, 6), as well as organic dinoflagellate cysts characteristic for upwelling relaxation phases (CD-upw relax). The contribution of $E$. huxleyi and accompanying coccolithophore taxa, and upwellingrelaxation organic dinoflagellate cysts, shows highest relative values from early fall through early spring and decreases into the most intense upwelling season (when G. oceanica increases, Fig. 4b). As such, this group also bears some resemblance to group 2, though coastal and open-ocean water diatoms are components of the latter, while diatoms are absent in group 4. This difference possibly reflects the distinct nutrient and water depth conditions in which E. huxleyi and other coccolithophores (group 4) and diatoms (group 2) typically thrive.

\subsection{Shifts in the species-specific composition of assemblages between 2004 and 2006}

The persistent seasonal pattern of the group and species occurrences experiences occasional shifts. Several events, which altered the regular pattern of temporal occurrence of species or groups of species at site $\mathrm{CBeu}$, were observed between late 2004 and late 2006 (Fig. 7f-j). We identify three main shift stages in the species-specific composition of assemblages:

1. Stage 1 (2004). (i) We observe a low total biogenic production (summer-fall 2004, Fig. 2b-d) and (ii) the absence of warm-water foraminifera (Fig. 7f). These changes in production or fluxes were accompanied by (iii) a significant decrease in SST as reconstructed with $U_{37}^{K^{\prime}}$ (Fig. 7d).

2. Stage 2 (late 2005 to early 2006). (i) We observe an extraordinarily high relative contribution of the coccolithophore U. anulus (Fig. 7i); as well as (ii) the first high occurrence of $L$. bulimoides and uncoiled pteropods (Fig. 7h).

3. Stage 3 (after fall 2006). (i) We observe a strong increase in the relative contribution of benthic diatoms (Fig. 7i) and warm-water calcareous dinoflagellates (Fig. 7j) and (ii) highest, longest occurrence and highest relative abundance of L. bulimoides (fall 2006 to winter 2007, Fig. 7h).

A certain degree of interannual variability of the physical setting (Mittelstaedt, 1983, 1991; Cropper et al., 2014) might explain the shifts in the species-specific composition of the assemblages. The near-disappearance of warm-water planktonic foraminifera in 2004 (Fig. 7f) was most probably the response to lower-than-usual water temperatures (Fig. 7d). However, the SST decrease is not recorded by satellite imagery. The overall climate evolution indicates a longer warm and dry period from 2001-2004 in the Sahel and Sahara (east of site $\mathrm{CBeu}$ ) and anomalously warm temperatures in the eastern Atlantic (Zeeberg et al., 2008; Alheit et al., 2014). Year 2004 is the only year of our study with noticeable temporal discrepancies between satellite and $U_{37}^{K^{\prime}}$-based temperature (Fig. 7d). This temperature gap suggests a certain decoupling between the temperature signal of the uppermost centimeters of the water column (satellite) and subsurface waters where the alkenone-forming coccolithophores dwell (E. huxleyi and G. oceanica; Conte et al., 1995). As planktonic foraminifera mainly react to SST variability (Kucera, 2007), cooler than usual subsurface waters between middle winter and early fall 2004 (Fig. 7d) might have been responsible for the strong decrease in the warm-water planktonic foraminifera contribution (Fig. 7f). Additionally, all other plankton groups show lowest fluxes toward late summer. Neither the seasonal pattern nor the MLD shows any significant change, and unusually high lithogenic fluxes did not occur (Figs. 2e, 7e). Exceptionally, the winter season 2004/2005 is characterized by a high total mass flux (Fig. 2a); this extraordinarily high seasonal value matches well with the highest fluxes of $\mathrm{TOC}$ and $\mathrm{CaCO}_{3}$ for the studied interval.

The extraordinarily high relative abundance of $U$. anulus in fall 2005 has not yet been observed in similar or other settings, although it is often listed in studies of large-scale distribution patterns of coccolithophores (e.g., Böckel and Baumann, 2008; Estrada et al., 2016; Poulton et al., 2017). So far only Steinmetz (1991) has found $U$. anulus (described as U. calvata and U. scituloma) in "frequent" abundances in sediment traps deployed in the equatorial Atlantic, central Pacific, and in the Panama Basin but without adding detailed information such as fluxes, the timing of its occurrence or its ecological significance. In most of the earlier trap studies, $U$. anulus has been grouped together with other Umbilicosphaera coccolithophores, since it did not reach high abundances (e.g., Köbrich et al., 2016; Guerreiro et al., 2017). Nevertheless, umbilicosphaerids seem to favor warm and more oligotrophic conditions (Baumann et al., 2016) so that the increased input of tropical surface waters transported northward via the MC (Mittelstaedt, 1991) can be possibly responsible for the advection of $U$. anulus upon the CBeu site.

The shift in the pteropod composition from dominating $H$. inflatus towards the appearance of $L$. bulimoides between winter 2005 and spring 2006 - and again in fall and winter 2006/2007 (Fig. 7h) - can be also explained by the increased influence of warmer surface waters of southern origin. Heliconoides inflatus is known as a rather cosmopolitan species, occurring across a wide range of oceanic provinces (Bé and Gilmer, 1977; Burridge et al., 2017), whereas L. bu- 
limoides seems to prefer waters of subtropical gyres (although it was also present in low numbers in the equatorial region; Burridge et al., 2017). A stronger transport of the MC from the south may have led to the deterioration of the adequate environmental conditions for $H$. inflatus, as can be seen by the extremely low total pteropods flux during winter 2005 to spring 2006 (Fig. 3e), and thus to the relative enrichment of $L$. bulimoides. The fact that the latter species is absent again in winter 2008 (Fig. 7h) represents a gradual return to previous (regular) winter conditions. Regular temperatures from early 2005 on allowed for the reappearance of warmwater planktonic foraminifera in fall 2005 (Fig. 7f).

The exceptional increase in the contribution of the benthic diatoms in spring/summer 2006 (Fig. 7i) might have been related to the intensification of lateral advection upon the intermediate waters deployed near the CBeu trap (Romero and Fischer, 2017). Observational and model experiments show that the transport of particles from the Mauritanian shelf and the uppermost slope via nepheloid layers significantly contributes to the deposition upon the lowermost slope and beyond than the direct vertical settling of particles from the surface layer (Nowald et al., 2014; Karakaş et al., 2006; Fischer et al., 2009; Zonneveld et al., 2018). The relevance of advective processes within nepheloid layers has been already proposed for similar settings (Puig and Palanques, 1998; Inthorn et al., 2006). We speculate that the longer predominance of N-NE winds between 2005 and 2007 (Fig. 7a) might have possibly intensified the transport of benthic diatoms from the shallow coastal area into the hemipelagic CBeu trap via the MC (Fig. 1). Enhanced lateral transport has important environmental implications for the final burial of organic matter in EBUEs. As the organic matter can be effectively displaced from the area of production (Inthorn et al., 2006), carbon depocenters generally occur at the continental slopes between 500 and $2000 \mathrm{~m}$. In the CC-EBUE around Cap Blanc, the depocenter with up to $3 \%$ of organic carbon has a depth range between 1000 and $2000 \mathrm{~m}$ (Fischer et al., 2019).

Most of the populations affected by and responding to shifting environmental conditions off Mauritania between 2004 and 2006 returned to their regular seasonal pattern of occurrence after 2006 (Fig. 4). However, some shifts persisted after summer 2006. Limacina bulimoides still dominated the pteropod assemblage (Fig. 7h); the total pteropod flux showed the highest maxima for the entire studied interval (which might be due to the large food supply and organic matter as represented by high total fluxes of diatoms, Fig. 3a, e), and warm-water calcareous dinoflagellate cysts increased during late fall 2006 (Fig. 7j). An exception to this pattern is the high relative contribution of benthic diatoms (Figs. 4a, 7i; Romero and Fischer, 2017). At this stage, we cannot fully disregard that the shift in the species-specific composition of the diatom community (also present after 2008; Romero and Fischer, 2017; Oscar E. Romero, unpublished observations, 2019) might be due to the natural long-term variability due to external forcings (e.g., North Atlantic Oscillation) or due to on-going climate change.

Our multiannual trap experiment provides a unique opportunity to study the long-term evolution of the plankton community in an ecologically important EBUE. Rapid shifts in the population contribution at site $\mathrm{CBeu}$ demonstrate that calcareous, siliceous and organic plankton microorganisms rapidly react to environmental changes in the CC-EBUE off Mauritania. Time-series trap experiments continuously conducted over many years - as those currently in the CC-EBUE (Fischer et al., 2016, 2019; Romero et al., 2002, 2016, 2017) - deliver a reliable observational basis on the occurrence of long-lasting variations of populations in response to key environmental forcings. Among others, our multiannual observations are useful for future model experiments on plankton dynamics and evolution in low- and mid-latitude EBUEs and how organisms influencing the global carbon cycle might react to global and ocean warming.

\section{Conclusions}

- The seasonal amplitude of the flux variations of primary and secondary producers in the upper water column off Mauritania was well recorded in our continuous trap experiment that lasted $1900 \mathrm{~d}$. The repeated yearly pattern of higher fluxes of diatoms, coccolithophores, organic-walled dinoflagellate cysts and planktonic foraminifera between early spring and early to middle summer matched well the temporal occurrence of the most intense upwelling interval in waters overlying site $\mathrm{CBeu}$. Conversely, fluxes of calcareous dinoflagellate cysts and pteropods were higher during intervals of upwelling relaxation (late summer through late fall).

- The good temporal match between maxima of (most of) the studied microorganism groups and biogenic bulk components unambiguously provides evidence to show that the contribution of primary and secondary producers to the total mass/biogenic mass fluxes. The notorious coupling between fluxes of lithogenic material and major microorganism groups provides compelling evidence for the biological pump off Mauritania to be strongly dependent on the dust input from the Sahara and Sahel and the eolian-transported nutrient deposition.

- $1900 \mathrm{~d}$ of continuous trap record of microorganism fluxes allowed for the recognition of a general sequence of seasonal variations of the main plankton populations thriving in coastal waters off Mauritania. The temporal turnover (succession) was better shown by the temporal variations of particular species or groups of species.

- A significant shift in the regular seasonal pattern of population occurrence was recognized in species rel- 
Table 5. Species composition of the assemblage of (a) diatoms, (b) coccolithophores, (c) calcareous and (d) organic dinoflagellate cysts, (e) planktonic foraminifera, and (f) pteropods at site CBeu between June 2003 and March 2008.

\begin{tabular}{|c|c|c|}
\hline \multicolumn{2}{|c|}{ (a) Diatoms } & \multirow{2}{*}{$\begin{array}{l}\text { References } \\
\text { Round et al. (1990) }\end{array}$} \\
\hline (1) & $\begin{array}{l}\text { Benthic } \\
\text { Actinoptychus spp. } \\
\text { Amphora spp. } \\
\text { Cocconeis spp. } \\
\text { Cymatosira belgica } \\
\text { Delphineis surirella } \\
\text { Grammatophora marina } \\
\text { Licmophora sp. } \\
\text { Odontella mobiliensis } \\
\text { Psammodyction panduriformis } \\
\text { Tabullaria } \text { spp. }\end{array}$ & \\
\hline (2) & $\begin{array}{l}\text { Coastal upwelling } \\
\text { Resting spores of } \\
\text { Chaetoceros affinis } \\
\text { Chaetoceros cinctus } \\
\text { Chaetoceros compresus } \\
\text { Chaetoceros constrictus } \\
\text { Chaetoceros coronatus } \\
\text { Chaetoceros debilis } \\
\text { Chaetoceros diadema } \\
\text { Chaetoceros radicans }\end{array}$ & Hasle and Syvertsen (1996) \\
\hline (3) & $\begin{array}{l}\text { Coastal planktonic } \\
\text { Actinocyclus curvatulus } \\
\text { Actinocyclus octonarius } \\
\text { Actinocyclus subtilis } \\
\text { Chaetoceros concavicornis (vegetative cell, VC) } \\
\text { Chaetoceros lorenzianus (VC) } \\
\text { Chaetoceros pseudobrevis (VC) } \\
\text { Coscinosdiscus argus } \\
\text { Coscinosdiscus decrescens } \\
\text { Coscinosdiscus radiatus } \\
\text { Cyclotella litoralis } \\
\text { Skeletonema costatum } \\
\text { Thalassionema nitzschioides var. capitulata } \\
\text { Thalassiosira angulata } \\
\text { Thalassiosira conferta } \\
\text { Thalassiosira oestrupii var. venrickae } \\
\text { Thalassiosira poro-irregulata }\end{array}$ & $\begin{array}{l}\text { Crosta et al. (2012), Romero et al. (2009a, b, } \\
\text { 2016, 2017), Romero and Armand (2010) }\end{array}$ \\
\hline (4) & $\begin{array}{l}\text { Open ocean } \\
\text { Asteromphalus flabellatus } \\
\text { Asteromphalus sarcophagus } \\
\text { Azpetia neocrenulata } \\
\text { Azpetia nodulifera } \\
\text { Azpetia tabularis } \\
\text { Detonula pumila } \\
\text { Dytilum brightwellii } \\
\text { Fragilariopsis doliolus } \\
\text { Hemiaulus hauckii } \\
\text { Hemidiscus membranaceus } \\
\text { Leptocyclindrus mediterraneus } \\
\text { Neodelphineis denticula } \\
\text { Nitzschia bicapitata } \\
\text { Nitzschia capuluspalae } \\
\text { Nitzschia interruptestriata } \\
\text { Nitzschia sicula } \\
\text { Planktoniella sol }\end{array}$ & $\begin{array}{l}\text { Hasle and Syvertsen (1996), Romero et } \\
\text { al. (2005), Crosta et al. (2012) }\end{array}$ \\
\hline
\end{tabular}


Table 5. Continued.

\begin{tabular}{l}
\hline (a) Diatoms \\
\hline Pseudo-nitzschia inflata var. capitata \\
Pseudo-nitzschia pungens \\
Pseudo-nitzschia subfraudulenta \\
Pseudosolenia calcar-avis \\
Pseudotriceratium punctatum \\
Rhizosolenia acuminata \\
Rhizosolenia bergonii \\
Rhizosolenia imbricatae \\
Rhizosolenia setigera \\
Roperia tessellata \\
Stellarima stellaris \\
Thalassionema bacillare \\
Thalassionema frauenfeldii \\
Thalassionema nitzschioides var. capitulata \\
Thalassionema nitzschioides var. inflata \\
Thalassionema nitzschioides var. parva \\
Thalassiosira eccentrica \\
Thalassionema endoseriata \\
Thalassiosira ferelineata \\
Thalassiosira lineata \\
Thalassiosira nanolineata \\
Thalassiosira oestrupii var. oestrupii \\
Thalassiosira sacketii var. sacketii \\
Thalassiosira sacketii var. plana \\
Thalassiosira subtilis \\
Thalassiosira symmetrica
\end{tabular}

(b) Coccolithophores

(1) Cosmopolitan

Emiliania huxleyi

Gephyrocapsa oceanica

(2) Lower photic zone

Algirosphaera robusta

Calciosolenia murrayi

Florisphaera profunda

Gladiolithus flabellatus

Hayaster perplexus

(3) Warm oligotrophic surface waters

Discosphaera tubifera

Helicosphaera carteri

Rhabdosphaera xiphos

Umbellosphaera irregularis

Umbellosphaera tenuis

Umbilicosphaera anulus

Umbilicosphaera sibogae

(4) Other miscellaneous species Acanthoica quattrospina Calcidiscus leptoporus

Calcidiscus leptoporus small

Calcidiscus quadriperforatus

Gephyrocapsa ericsonii

Gephyrocapsa muellerae

Ophiaster hydroideus

Ophiaster hydroideus

Rhabdosphaera stylifer

Syracosphaera anthos

Syracosphaera pulchra
Böckel and Baumann (2008), Baumann and Böckel (2013), Poulton et al. (2017), Young et al. (2019) 
Table 5. Continued.

(c) Calcareous dinoflagellates cysts

\begin{tabular}{|c|c|c|}
\hline (1) & $\begin{array}{l}\text { Upwelling } \\
\text { Calciodinellum operosum } \\
\text { Scrippsiella trochoidea }\end{array}$ & $\begin{array}{l}\text { Siggelkow et al. (2002), Richter et al. (2007), } \\
\text { Kohn and Zonneveld (2010) }\end{array}$ \\
\hline (2) & $\begin{array}{l}\text { Warm waters } \\
\text { Calciodinellum albatrosianum }\end{array}$ & \\
\hline (3) & $\begin{array}{l}\text { Mineral input } \\
\text { Leonella granifera }\end{array}$ & \\
\hline (4) & $\begin{array}{l}\text { Cosmopolitan } \\
\text { Thoracosphaera heimii }\end{array}$ & \\
\hline (5) & $\begin{array}{l}\text { Others } \\
\text { Calciodinellum levantinum } \\
\text { Melodemuncula berlinensis } \\
\text { Pernambugia tuberosa } \\
\text { Scrippsiella lacrymosa } \\
\text { Scrippsiella regalis } \\
\text { Scrippsiella trifida }\end{array}$ & \\
\hline
\end{tabular}

(d) Organic dinoflagellates cysts

(1) Upwelling Echinidinium aculeatum Echinidinium granulatum Echinidinium transparantum Echinidinium zonneveldiae Echinidinium spp. cyst of Protoperidinium americanum cyst of Protoperidinium monospinum Stelladinium stellatum

(2) Upwelling relaxation Lingulodinium machaerophorum cyst of Polykrikos schwartzii cyst of Polykrikos kofoidii

(3) Potential toxic cysts of Gymnodinium spp. cysts of Alexandrium spp.

(4) Cosmopolitan Brigantedinium spp. Spiniferites species Impagidinium species

(e) Planktonic foraminifera

(1) Warmer waters Globigerinoides ruber (pink and white) Globigerinoides sacculifer

(2) Cooler waters Globorotalia inflata Neogloboquadrina incompta

(3) Upwelling Globigerina bulloides
Susek et al. (2005), Holzwarth et al. (2010), Trainer et al. (2010), Smayda (2010), Smayda and Trainer (2010), Zonneveld et al. (2010, 2013)
Hemleben et al. (1989), Schiebel and Hemleben (2017) 
Table 5. Continued.

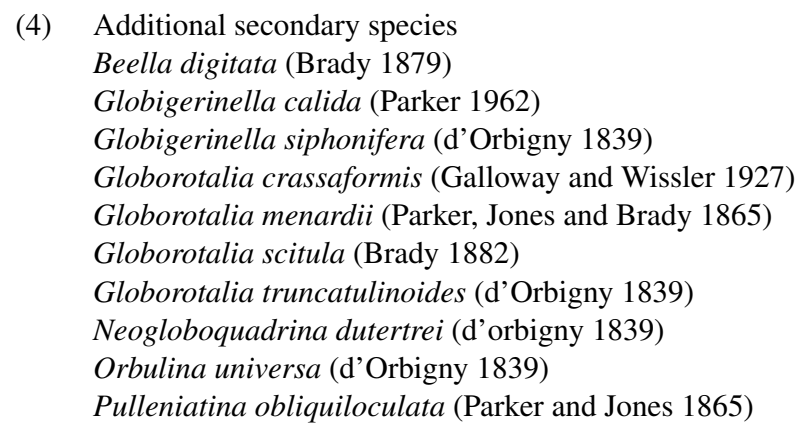

(f) Pteropods

Heliconoides inflatus (d'Orbigny 1835, formerly known as Limacina inflata) WoRMS Editorial Board (2017)

Limacina bulimoides (d'Orbigny 1835)

ative contributions between 2004 and 2006. Several events altering the regular seasonal pattern were observed and occurred in three main stages: summerfall 2004, late 2005 to early 2006 and after fall 2006 . Although most of the populations return "to normal" after fall 2006, a few did not.

- Our multiannual trap experiment emphasizes the significance of long-term records on evaluating the impact of changing environmental conditions on living populations. Time-series trap experiments conducted over many years - as those currently conducted in the CCEBUE by MARUM - deliver a broad observational basis on the occurrence of persistent seasonal and interannual patterns. They also help in the interpretation of long-lasting variations of population changes in response to key environmental forcings, such as nutrient input, water masses variability, lateral transport and/or climate change. The applicability of the flux dynamics of primary and secondary producers here presented is not limited to the Mauritanian upwelling system, and it might be comparable to other EBUEs.

Data availability. Data are available at https://doi.pangaea.de/10. 1594/PANGAEA.904390 (Romero et al., 2019).

Author contributions. All authors collected the data. OER wrote the article. All authors contributed to the interpretation of results and discussions.

Competing interests. The authors declare that they have no conflict of interest.
Acknowledgements. We are greatly indebted to the masters and crews of the RV Poseidon and RV MS Merian. We greatly appreciate the help of the RV Poseidon headquarters at Geomar (Klas Lackschewitz, Kiel, Germany) during the planning phases of the research expeditions and the support by the German, Moroccan and Mauritanian authorities in Berlin, Rabat and Nouakchott. We also thank the IMROP and its director at Nouadhibou (Mauritania) for their general support and the help in getting the necessary permissions to perform our multiyear trap experiments in Mauritanian coastal waters. We thank Götz Ruhland, Nicolas Nowald and Marco Klann (MARUM, Bremen) for mooring deployments and lab work on the samples. This work was possible due to the longterm funding by the German Research Foundation (DFG) through SFB 261, the Research Center Ocean Margins (RCOM) and the MARUM Excellence Cluster "The Ocean in the Earth System" (University of Bremen, Bremen, Germany). Vera Pospelova is the Hanse-Wissenschaftskolleg (HWK) senior research fellow in marine and climate research at the Institute for Advanced Study (Delmenhorst, Germany). Manuel Bringué and an anonymous referee are acknowledged for their very helpful reviews.

Financial support. The article processing charges for this openaccess publication were covered by the University of Bremen.

Review statement. This paper was edited by Emilio Marañón and reviewed by Manuel Bringué and one anonymous referee.

\section{References}

Alheit, J., Licandro, P., Coombs, S., Garcia, A., Giráldez, A., Santamaría, M. T. G., Slotte, A., and Tsikliras, A. C.: Atlantic Multidecadal Oscillation (AMO) modulates dynamics of small pelagic fishes and ecosystem regime shifts in the eastern North and Central Atlantic, J. Marine Syst., 133, 88-102, 2014.

Anabalón, V., Arístegui, J., Morales, C. E., Andrade, I., Benavides, M., Correa-Ramírez, M. A., Espino, M., Ettahiri, O., Hormaza- 
bal, S., Makaoui, A., Montero, M. F., and Orbi, A.: The structure of planktonic communities under variable coastal upwelling conditions off Cape Ghir $\left(31^{\circ} \mathrm{N}\right)$ in the Canary Current System (NW Africa), Prog. Oceanogr., 120, 320-339, 2014.

Arístegui, J., Barton, E. C., Álvarez-Salgado, X. A., Santos, A. M. P., Figueiras, F. G., Kifani, S., Hernández-León, S., Mason, E., Machú, E., and Demarcq, H.: Sub-regional ecosystem variability in the Canary Current upwelling, Prog. Oceanogr., 83, 33-48, 2009.

Barber, R. T. and Hiscock, M. R.: A rising tide lifts all phytoplankton: Growth response of other phytoplankton taxa in diatomdominated blooms, Global Biogeochem. Cy., 20, GB4S03, https://doi.org/10.1029/2006GB002726, 2006.

Barton, E. D.: Eastern Boundary of the North Atlantic: Northwest Africa and Iberia, in: The Sea, edited by: Robinson A. R. and Brink, K. H., 11, 633-657, 1998.

Baumann, K.-H. and Böckel, B.: Spatial distribution of living coccolithophores in the southwestern Gulf of Mexico, J. Micropaleontol., 32, 123-133, 2013.

Baumann, K.-H. and Freitag, T.: Pleistocene fluctuations in the Benguela Current system as revealed by coccolith assemblages, Mar. Micropaleontol., 52, 195-215, 2004.

Baumann, K.-H., Andruleit, H., Böckel, B., Geisen, M., and Kinkel, H.: The significance of extant coccolithophores as indicators of ocean water masses, surface water temperature, and paleoproductivity: a review, Paläontolog. Zeitschr., 79, 93-112, 2005.

Baumann, K.-H., Saavedra-Pellitero, M., Böckel, B., and Ott, C.: Morphometry, biogeography and ecology of Calcidiscus and Umbilicosphaera in the South Atlantic, Rev. Micropaleontol., 59, 239-251, https://doi.org/10.1016/j.revmic.2016.03.001, 2016.

Bé, A. W. H. and Gilmer, R. W.: A zoographic and taxonomic review of euthecosomatous pteropoda, in: Oceanic Micropalaeontology, vol. 1, edited by: Ramsay, A. T. S., Academic Press, London, 733-808, 1977.

Böckel, B. and Baumann, K.-H.: Vertical and lateral variations in coccolithophore community structure across the subtropical frontal zone in the South Atlantic Ocean, Mar. Micropaleontol., 67, 255-273, 2008.

Bory, A., Jeandel, C., Leblond, N., Vangriesheim, A., Khripounoff, A., Beaufort, L., Rabouille, C., Nicolas, E., Tachikawa, F., Etcheber, H., and Buat-Ménard, P.: Downward particle fluxes within different productivity regimes off the Mauritanian upwelling zone (EUMELI program), Deep-Sea Res. Pt. I, 48, 22512282, 2001.

Bouimetarhan, I., Marret, F., Dupont, L., and Zonneveld, K. A. F.: Dinoflagellate cyst distribution in marine surface sediments off West Africa $\left(17-6^{\circ} \mathrm{N}\right)$ in relation to sea-surface conditions, freshwater input and seasonal coastal upwelling, Mar. Micropaleontol., 71, 113-130, 2009.

Bringué, M., Thunell, R. C., Pospelova, V., Pinckney, J. L., Romero, O. E., and Tappa, E. J.: Physico-chemical and biological factors influencing dinoflagellate cyst production in the Cariaco Basin, Biogeosciences, 15, 2325-2348, https://doi.org/10.5194/bg-152325-2018, 2018.

Bringué, M., Pospelova, V., Tappa, E. J., and Thunell, R. C.: Dinoflagellate cyst production in the Cariaco Basin: a 12.5 yearlong sediment trap study, Prog. Oceanogr., 171, 175-211, 2019.

Buesseler, K. O., Antia, A. A., Chen, M., Fowler, S. W., Gardner, W. D., Gustafsson, O., Harada, K., Michaels, A. F., Rutgers van der Loeff, M., Sarin, M., Steinberg, D. K., and Trull, T.: An assessment of the use of sediment traps for estimating upper ocean particle fluxes, J. Mar. Res., 65, 345-416, 2007.

Burridge, A. K., Goetze, E., Wall-Palmer, D., Le Double, S. L., Huisman, J., and Peijnenburg, K. T. C. A.: Diversity and abundance of pteropods and heteropods along a latitudinal gradient across the Atlantic Ocean, Prog. Oceanogr., 158, 213-223, 2017.

Chavez, F. P. and Messié, M.: A comparison of Eastern Boundary Upwelling Ecosystems, Prog. Oceanogr., 83, 80-96, 2009.

Conte, M. H., Thompson, A., Egrinton, G., and Green, J. C.: Lipid biomarker diversity in the coccolithophorid Emiliania huxleyi (Prymnesiophyceae) and the related species Gephyrocapsa oceanica, J. Phycol., 31, 272-282, 1995.

Conte, M. H., Sicre, M., Rühlemann, C., Weber, J. C., Schulte, S., Schulz-Bull, D., and Blanz, T.: Global temperature calibration of the alkenone unsaturation index $\left(U_{37}^{K^{\prime}}\right)$ in surface waters and comparison with surface sediments, Geochem. Geophy. Geosy., 7, 1-22, https://doi.org/10.1029/2005GC001054, 2006.

Cropper, T. E., Hanna, E., and Bigg, G. R.: Spatial and temporal seasonal trends in coastal upwelling off Northwest Africa, 19812012, Deep-Sea Res. Pt. I, 86, 94-111, 2014.

Crosta, X., Romero, O. E., Ther, O., and Schneider, R. R.: Climatically-controlled siliceous productivity in the eastern Gulf of Guinea during the last $40000 \mathrm{yr}$, Clim. Past, 8, 415-431, https://doi.org/10.5194/cp-8-415-2012, 2012.

Elbrächter, M., Gottschling, M., Hildebrand-Habel, T., Keupp, H., Kohring, R., Lewis, J., Meier, K. J. S., Montresor, M., Streng, M., Versteegh, G. J. M., Willems, H., and Zonneveld, K.: Establishing an agenda for calcareous dinoflagellate research (Thoracosphaeraceae, Dinophyceae) including a nomenclatural synopsis of generic names, Taxon, 57, 1289-1303, 2008.

Estrada, M., Delgado, M., Blasco, D., Latasa, M., Cabello, A. M., Benítez-Barrios, V., Fraile-Nuez, E., Mozetic, P., and Vidal, M.: Phytoplankton across Tropical and Subtropical Regions of the Atlantic, Indian and Pacific Oceans, PLoS ONE, 11, 3, e0151699. https://doi.org/10.1371/journal.pone.0151699, 2016.

Fischer, G. and Karakaş, G.: Sinking rates and ballast composition of particles in the Atlantic Ocean: implications for the organic carbon fluxes to the deep ocean, Biogeosciences, 6, 85102, https://doi.org/10.5194/bg-6-85-2009, 2009.

Fischer, G. and Wefer, G.: Sampling, preparation and analysis of marine particulate matter, in: The Analysis and Characterization of Marine Particles, edited by: Hurd, D. C. and Spencer, D. W., Geophysical Monograph Series, 63, 391-397, 1991.

Fischer, G., Donner, B., Ratmeyer, V., Davenport, R., and Wefer, G.: Distinct year-to-year particle flux variations off Cape Blanc during 1988-1991: Relation to $\delta^{18} \mathrm{O}$-deduced sea-surface temperatures and trade winds, J. Mar. Res., 54, 73-98, 1996.

Fischer, G., Reuter, C., Karakaş, G., Nowald, N., and Wefer, G.: Offshore advection of particles within the Cape Blanc filament, Mauritania: Results from observational and modelling studies, Progr. Oceanogr., 83, 322-330, https://doi.org/10.1016/j.pocean.2009.07.023, 2009.

Fischer, G., Romero, O., Merkel, U., Donner, B., Iversen, M., Nowald, N., Ratmeyer, V., Ruhland, G., Klann, M., and Wefer, G.: Deep ocean mass fluxes in the coastal upwelling off Mauritania from 1988 to 2012: variability on seasonal to decadal timescales, Biogeosciences, 13, 3071-3090, https://doi.org/10.5194/bg-13-3071-2016, 2016. 
Fischer, G., Romero, O. E., Toby, E., Iversen, M., Donner, B., Mollenhauer, G., Nowald, N., Ruhland, G., Klann, M., Hamady, B., and Wefer, G.: Changes in the Dust-Influenced Biological Carbon Pump in the Canary Current System: Implications From a Coastal and an Offshore Sediment Trap Record Off Cape Blanc, Mauritania, Global Biogeochem. Cy., 33, 1100-1128, https://doi.org/10.1029/2019GB006194, 2019.

Friese, C. A., van Hateren, J. A., Vogt, C., Fischer, G., and Stuut, J.B. W.: Seasonal provenance changes in present-day Saharan dust collected in and off Mauritania, Atmos. Chem. Phys., 17, 1016310193, https://doi.org/10.5194/acp-17-10163-2017, 2017.

Fütterer, D. K.: The modern upwelling record off Northwest Africa, in: Coastal Upwelling, its sediment record, Part B, Sedimentary records of ancient coastal upwelling, edited by: Thiede, J. and Suess, E., NATO Conference Series IV, Marine Science, Springer Verlag US, Boston, MA, pp. 105-121, 1983.

Gabric, A. J., García, L., Van Camp, L., Nykjaer, L., Eifler, W., and Schrimpf, W.: Offshore Export of Shelf Production in the Cape Blanc (Mauritania) Giant Filament as Derived from Coastal Zone Color Scanner Imagery, J. Geophys. Res., 98, 4697-4712, 1993.

Guerreiro, C. V., Baumann, K.-H., Brummer, G.-J. A., Fischer, G., Korte, L. F., Merkel, U., Sá, C., de Stigter, H., and Stuut, J.-B. W.: Coccolithophore fluxes in the open tropical North Atlantic: influence of thermocline depth, Amazon water, and Saharan dust, Biogeosciences, 14, 4577-4599, https://doi.org/10.5194/bg-144577-2017, 2017.

Guerreiro, C. V., Baumann, K.-H., Brummer, G.-J. A., Korte, L. F., de Sá, C., and Stuut, J.-B.: Transatlantic gradients in calcifying phytoplankton (coccolithophores) fluxes, Progr. Oceanogr., 176, https://doi.org/10.1016/j.pocean.2019.102140, 2019.

Hagen, E.: Northwest African upwelling scenario, Oceanol. Acta, 24, S113-S128, 2001.

Hardy, W., Marret, F., Penaud, A., le Mézo, P., Droz, L., Marsset, T., and Kageyama, M.: Quantification of last glacial-Holocene net primary productivity and upwelling activity in the equatorial eastern Atlantic with a revised modern dinocyst database, Palaeogeogr. Palaeoecol., 505, 410-427, 2018.

Hasle, G. A. and Syvertsen, E. E.: Marine diatoms, in: Identifying marine diatoms and dinoflagellates, edited by: Thomas, C., Academic Press, Inc. San Diego, CA, 1-385, 1996.

Hedges, J. I., Baldock, J. A., Gélinas, Y., Lee, C., Peterson, M. L., and Wakeham, S. G.: The biochemical and elemental compositions of marine plankton: A NMR perspective, Mar. Chem., 78, 47-63, 2002.

Helmke, P., Romero, O. E., and Fischer, G.: Northwest African upwelling and its effect on off-shore organic carbon export to the deep sea, Global Biogeochem. Cycles, 19, GB4015, https://doi.org/10.1029/2004GB002265, 2005.

Hemleben, C., Spindler, C., and Anderson, O. R.: Modern Planktonic Foraminifera, 363 pp., Springer, New York, 1989.

Holzwarth, U., Esper, O., and Zonneveld, K. A. F.: Organic-walled dinoflagellate cysts as indicators of oceanographic conditions and terrigenous input in the NW African upwelling region, Rev. Palaeobot. Palyno., 159, 35-55, 2010.

Inthorn, M., Wagner, T., Scheeder, G., and Zabel, M.: Lateral transport controls distribution, quality, and burial of organic matter along continental slopes in high-productivity areas, Geology, 34, 205-208, https://doi.org/10.1130/G22153.1, 2006.
IOC-UNESCO TS129 IGMETS: What are Marine Ecological Time Series telling us about the ocean? A status report, IOC Technical Series, IOC, UNESCO, Paris Cedex 07SP, France, 129 pp., 2017.

Iversen, M. H. and Ploug, H.: Ballast minerals and the sinking carbon flux in the ocean: carbon-specific respiration rates and sinking velocity of marine snow aggregates, Biogeosciences, 7 , 2613-2624, https://doi.org/10.5194/bg-7-2613-2010, 2010.

Iversen, M. H., Nowald, N., Ploug, H., Jackson, G. A., and Fischer, G.: High resolution profiles of vertical particulate organic matter export off Cape Blanc, Mauritania: Degradation processes and ballasting effects, Deep-Sea Res. Pt. I, 57, 771-784, 2010.

Jiménez-Quiroz, M. D. C., Cervantes-Duarte, R., Funes-Rodríguez, R., Barón-Campis, S. A., García-Romaro, F. D. J., HernándezTrujillo, S., Hernández-Becerril, D. U., González-Armas, L. V., Martell-Dubois, R., Cerdeira-Estrada, S., Fernández-Mémdez, J., González-Ania, L. V., Vásquez-Ortiz, M., and Barrón-Barraza, F. J.: Impact of "The Blob" and "El Nino" in the SW Baja California Peninsula: Plankton and environmental variability of Bahia Magdalena, Front. Mar. Sci., 6, 1-23, 2019.

Jordan, R. W., Zhao, M., Eglinton, G., and Weaver, P. P. E.: Coccolith and alkenone stratigraphy and palaeoceanography at an upwelling site off NW Africa (ODP 658C) during the last 130000 years, in: Microfossils and oceanic environments, edited by: Moguilevsky, A. and Whatley, R., University of Wales, Aberystwyth Press, London, pp. 111-130, 1996.

Karakaş, G., Nowald, N., Blaas, M., Marchesiello, P., Frickenhaus, S., and Schlitzer, R.: High-resolution modeling of sediment erosion and particle transport across the northwest African shelf, J. Geophys. Res., 111, C06025, https://doi.org/10.1029/2005JC003296, 2006.

Karakaş, G., Nowald, N., Schäfer-Neth, C., Iversen, M., Barkmann, W., Fischer, G., Marchesiello, P., and Schlitzer, R.: Impact of particle aggregation on vertical fluxes of organic matter, Prog. Oceanogr., 83, 331-341, 2009.

Köbrich, M. I. and Baumann, K.-H.: Coccolithophore flux in a sediment trap off Cape Blanc (NW Africa), J. Nannopl., 30, 83-96, 2008.

Köbrich, M. I., Baumann, K.-H., and Fischer, G.: Seasonal and inter-annual dynamics of coccolithophore fluxes from the upwelling region off Cape Blanc, Northwest Africa, J. Micropaleontol., 35, 103-116, https://doi.org/10.1144/jmpaleo2014-024, 2016.

Kohn, M. and Zonneveld, K. A. F.: Calcification depth and spatial distribution of Thoracosphaera heimii cysts: Implications for palaeoceanographic reconstructions, Deep-Sea Res. Pt. I, 57, 1543-1560, 2010.

Kremling, K., Lentz, U., Zeitzschell, B., Schulz-Bull, D. E., and Duinker, J. C.: New type of time-series sediment trap for the reliable collection of inorganic and organic trace chemical substances, Rev. Sci. Instrument., 67, 4360-4363, 1996.

Kucera, M.: Planktonic foraminifera as tracers of past oceanic environments: in: Developments in Marine Geology, Volume 1, Proxies in Late Cenozoic Paleoceanography, edited by: HillaireMarcel, C. and De Vernal, A., Elsevier, Amsterdam, 213-262, 2007.

Lange, C. B., Romero, O. E., Wefer, G., and Gabric, A. J.: Offshore influence of coastal upwelling off Mauritania, NW Africa, as recorded by diatoms in sediment traps at $2195 \mathrm{~m}$ water depth, Deep-Sea Res. Pt. I, 45, 985-1013, 1998. 
Lathuilière, C., Echevin, V., and Levy, M.: Seasonal and intraseasonal surface chlorophyll-a variability along the northwest African coast, J. Geophys. Res.-Oceans, 13, C05007, https://doi.org/10.1029/2007JC004433, 2008.

Marcello, J., Hernández-Guerra, A., Eugenio, F., and Fonte, A.: Seasonal and temporal study of the northwest African upwelling system, Int. J. Remote Sens., 32, 1843-1859, 2011.

Margalef, R.: On certain unifying principles in ecology, Am. Nat., 97, 357-374, 1963.

McKay, C. L., Filipsson, H. L., Romero, O. E., Stuut, J.-B. W., and Donner, B.: Pelagic-benthic coupling within an upwelling system of the subtropical northeast Atlantic over the last $35 \mathrm{ka} \mathrm{BP}$, Quat. Sci. Rev., 106, 299-315, 2014.

Meunier, T., Barton, E. D., Barreiro, B., and Torres, R.: Upwelling filaments off Cape Blanc: interaction of the $\mathrm{NW}$ African upwelling current and the Cape Verde frontal zone eddy field?, J. Geophys. Res.-Oceans, 117, C8, C08031, https://doi.org/10.1029/2012JC007905, 2012.

Mittelstaedt, E.: The upwelling area off Northwest Africa - a description of phenomena related to coastal upwelling, Prog. Oceanogr., 12, 307-331, 1983.

Mittelstaedt, E.: The ocean boundary along the northwest African coast: Circulation and oceanographic properties at the sea surface, Prog. Oceanogr., 26, 307-355, 1991.

Mollenhauer, G., Basse, A., Kim, J.-H., Sinninghe Damsté, J. S., and Fischer, G.: A four-year record of $U_{37}^{K}-$ and $\mathrm{TEX}_{86}$-derived sea surface temperature estimates from sinking particles in the filamentous upwelling region off Cape Blanc, Mauritania, DeepSea Res. Pt. I, 97, 67-79, 2015.

Müller, P. and Fischer, G.: A 4-year sediment trap record of alkenones from the filamentous region off Cape Blanc, NW Africa, and a comparison with distributions in underlying sediments, Deep-Sea Res. Pt. I, 48, 1877-1903, 2001.

Müller, P. J. and Schneider, R. R.: An automated leaching method for the determination of opal in sediments and particulate matter, Deep-Sea Res. Pt. I, 40, 425-444, 1993.

Muller-Karger, F., Varela, R., Thunell, R., Luerssen, R., Hu, C., and Walsh, J. J.: The importance of continental margins in the global carbon cycle, Geophys. Res. Lett., 32, L01602, https://doi.org/10.1029/2004GL021346, 2005.

Nicholson, S. E.: The West African Sahel. A review of recent studies on the rainfall regime and its interannual variability, ISRN Meteorology, 2013, 453521, https://doi.org/10.1155/2013/453521, 2013.

Nowald, N., Iversen, M. H., Fischer, G., Ratmeyer, V., and Wefer, G.: Time series of in-situ particle properties and sediment trap fluxes in the coastal upwelling filament off Cape Blanc, Mauritania, Prog. Oceanogr., 137, 1-11, 2014.

Pauly, D. and Christensen, V.: Primary production required to sustain global fisheries, Nature, 374, 255-257, 1995.

Pelegrí, J. L., Marrero-Díaz, A., and Ratsimandresy, A. W.: Nutrient irrigation of the North Atlantic, Prog. Oceanogr., 70, 366-406, 2006.

Pelegrí, J. L., Peña-Isquierdo, J., Machin, F., Meiners, C., and Presas-Navarro, C.: Oceanography of the Cape Verde Basin and Mauritanian Slope Waters, Research of Marine Biodiversity and Habitats in the Northwest African Margin, Springer, Berlin, 3, 119-153, https://doi.org/10.1007/978-94-024-1023-5_3, 2017.
Pospelova, V., Zonneveld, K. A. F., Heikkilä, M., Bringué, M., Price, A. M., Esenkulova, S., and Matsuoka, K.: Seasonal, annual, and inter-annual Spiniferites cyst production: a review of sediment trap studies, Palynology, 42, 162-182, 2018.

Poulton, A. J., Holligan, P. M., Charalampopoulou, A., and Adey, T. R.: Coccolithophore ecology in the tropical and subtropical Atlantic Ocean: New perspectives from the Atlantic meridional transect (AMT) Programme, Progr. Oceanogr., 158, 150-170, 2017.

Prahl, F. G. and Wakeham, S. G.: Calibration of unsaturation patterns in long-chain ketone compositions for palaeotemperature assessment, Nature, 330, 367-369, 1987.

Puig, P. and Palanques, A.: Nepheloid structure and hydrographic control on the Barcelona continental margin, northwestern Mediterranean, Mar. Geol., 149, 39-54, 1998.

Rembauville, M., Meilland, J., Ziveri, P., Schiebel, R., Blain, S., and Salter, I.: Planktic foraminifer and coccolith contribution to carbonate export fluxes over the central Kerguelen Plateau, Deep-Sea Res. Pt. I, 111, 91-101, https://doi.org/10.1016/j.dsr.2016.02.017, 2016.

Richter, D., Vink, A., Zonneveld, K. A. F., Kuhlman, H., and Willems, H.: Calcareous dinoflagellate cyst distributions in surface sediments from upwelling areas off NW Africa, and their relationships with environmental parameters of the upper water column, Mar. Micropal., 63, 201-228, 2007.

Roelke, D. L. and Spatharis, S.: Phytoplankton succession in recurrently fluctuating environments, PLoS One, 10, e0121392, https://doi.org/10.1371/journal.pone.0121392, 2015.

Romero, O. E. and Armand, L. K.: Marine diatoms as indicators of modern changes in oceanographic conditions, in: The Diatoms, Applications for the Environmental and Earth Sciences (Second Edition), edited by: Smol, J. P. and Stoermer, E. F., Cambridge University Press, Cambridge, 373-400, 2010.

Romero, O. E. and Fischer, G.: Shift in the species composition of the diatom community in the eutrophic Mauritanian coastal upwelling: Results from a multi-year sediment trap experiment (2003-2010), Prog. Oceanogr., 159, 31-44, 2017.

Romero, O. E., Lange, C. B., Fischer, G., Treppke, U. F., and Wefer, G.: Variability in export production documented by downward fluxes and species composition of marine planktonic diatoms: Observations from the tropical and equatorial Atlantic, in: Use of Proxies in Paleoceanography, Examples from the South Atlantic, edited by: Fischer, G. and Wefer, G., Springer Verlag, Berlin, Heidelberg, 365-392, 1999.

Romero, O. E., Lange, C. B., and Wefer, G.: Interannual variability (1988-1991) of siliceous phytoplankton fluxes off northwest Africa, J. Plank. Res., 24, 1035-1046, https://doi.org/10.1093/plankt/24.10.1035, 2002.

Romero, O. E., Dupont, L., Wyputta, U., Jahns, S., and Wefer, G.: Temporal variability of fluxes of eolian-transported freshwater diatoms, phytoliths, and pollen grains off Cape Blanc as reflection of land-atmosphere-ocean interactions in northwest Africa, J. Geophys. Res.-Oceans, 108, 3153, https://doi.org/10.1029/2000JC000375, 2003.

Romero, O. E., Armand, L. K., Crosta, X., and Pichon, J.-J.: The biogeography of major diatom taxa in Southern Ocean surface sediments: 3. Tropical/Subtropical species, Palaeogeogr. Palaeocl., 223, 49-65, 2005. 
Romero, O. E., Kim, J., and Donner, B.: Submillennial-tomillennial variability of diatom production off Mauritania, NW Africa, during the last glacial cycle, Paleoceanography, 23, PA3218, https://doi.org/10.1029/2008PA001601, 2008.

Romero, O. E., Rixen, T., and Herunadi, B.: Effects of hydrographic and climatic forcing on diatom production and export in the tropical southeastern Indian Ocean, Mar. Ecol. Prog. Ser., 384, 6982,2009 a.

Romero, O. E., Thunell, R. C., Astor, Y., and Varela, R.: Seasonal and interannual dynamics in diatom production in the Cariaco Basin, Venezuela, Deep-Sea Res. Pt. I, 56, 571-581, 2009 b.

Romero, O. E., Crosta, X., Kim, J.-H., Pichevin, L., and Crespin, J.: Rapid longitudinal migrations of the filament front off Namibia (SE Atlantic) during the past $70 \mathrm{kyr}$, Global Planet. Changes, 125, 1-12, https://doi.org/10.1016/j.gloplacha.2014.12.001, 2015.

Romero, O. E., Fischer, G., Karstensen, J., and Cermeño, P.: Eddies as trigger for diatom productivity in the open-ocean Northeast Atlantic, Prog. Oceanogr., 147, 38-48, 2016.

Romero, O. E., Fischer, G., Baumann, K.-H., Zonneveld, K. A. F., and Donner, B.: Fluxes of diatoms, coccolithophorids, calcareous and organic-walled dinoflagellate cysts, planktonic foraminifera and pteropods and the species-specific composition of the assemblages collected at the mooring site CBeu, PANGAEA, https: //doi.pangaea.de/10.1594/PANGAEA.904390, dataset in review, 2019.

Round, F. E., Crawford, R. M., and Mann, D. G.: The diatoms, Cambridge University Press, Cambridge, 747 pp., 1990.

Sancetta, C. and Calvert, S. E.: The annual cycle of sedimentation in Saanich Inlet, British Columbia: implications for the interpretation of diatom fossil assemblages, Deep-Sea Res., 35, 71-90, 1988.

Schlüter, M. H., Kraberg, A., and Wiltshire, K. H.: Long-term changes in the seasonality of selected diatoms related to grazers and environmental conditions, J. Sea Res., 67, 91-97, 2012.

Schiebel, R. and Hemleben, C.: Planktic Foraminifers in the Modern Ocean, Springer-Verlag GmbH Berlin, Heidelberg, 2017.

Schrader, H.-J. and Gersonde, R.: Diatoms and silicoflagellates, in: Micropaleontological counting methods and techniques - an exercise on an eight meter section of the Lower Pliocene of Capo Rosello, Sicily, edited by: Zachariasse, W. J., Riedel, W. R., Sanfilippo, A., Schmidt, R. R., Brolsma, M. J., Schrader, H., Gersonde, R., Drooger, M. M., and Broekman, J. A., Utrecht Micropaleontological Bulletin, Utrecht, 17, 129-176, 1978.

Siegel, D. A. and Deuser, W. G.: Trajectories of sinking particles in the Sargasso Sea: modeling of statistical funnels above deepocean sediment traps, Deep-Sea Res. Pt. I, 44, 1519-1541, 1997.

Siggelkow, D., Vink, A., and Willems, H.: Calcareous dinoflagellate cyst production, vertical transport and preservation off Cape Blanc during 1990: a sediment-trap study, J. Nannoplankton Res., 24, 160, 2002.

Skonieczny, C., Bory, A., Bout-Roumazeilles, V., Abouchami, W., Galer, S. J. G., Crosta, X., Diallo, A., and Ndiaye, T.: A threeyear time series of mineral dust deposits on the West African margin: Sedimentological and geochemical signatures and implications for interpretation of marine paleo-dust records, Earth Planet. Sc. Lett., 364, 145-156, 2013.
Smayda, T. J.: Ecological features of harmful algal blooms in coastal upwelling ecosystems, African J. Mar. Sci., 22, 219-253, 2010.

Smayda, T. J. and Trainer, V. L.: Dinoflagellate blooms in upwelling systems: Seeding, variability, and contrasts with diatom bloom behavior, Prog. Oceanogr., 85, 92-107, 2010.

Smilauer, P. and Leps, J.: Multivariate analysis of ecological data using Canoco 5, Cambridge University Press, Cambridge, 1-362, 2014.

Steinmetz, J. C.: Calcareous nannoplankton biocoenosis: sediment trap studies in the Equatorial Atlantic, Central Pacific, and Panama Basin, Woods Hole Oceanographic Institution, USA, 1, $1-85,1991$.

Susek, E., Zonneveld, K. A. F., Fischer, G., Versteegh, G. J., and Willems, H.: Organic-walled dinoflagellate cyst production in relation to upwelling intensity and lithogenic influx in the Cape Blanc region (off north-west Africa), Phycol. Res., 53, 97-112, 2005.

ter Braak, C. J. and Smilauer, P.: Canoco 5, Biometris, Wageningen, pp. 1-496, 2012.

Trainer, V. L., Pitcher, G. C., Reguera, B., and Smayda, T. J.: The distribution and impacts of harmful algal bloom species in eastern boundary upwelling systems, Prog. Oceanogr., 85, 33-52, 2010.

Van Camp, L., Nykjær, L., Mittelstaedt, E., and Schlittenhardt, P.: Upwelling and boundary circulation off Northwest Africa as depicted by infrared and visible satellite observations, Prog. Oceanogr., 26, 357-402, 1991.

van der Jagt, H., Friese, C., Stuut, J.-B. W., Fischer, G., and Iversen, M.: The ballasting effect of Saharan dust deposition on aggregate dynamics and carbon export: Aggregation, settling, and scavenging potential of marine snow, Limnol. Oceanogr., 63, 1386-1394, 2018.

Vink, A., Brune, A., Höll, C., Zonneveld, K. A. F., and Willems, H.: On the response of calcareous dinoflagellates to oligotrophy and stratification of the upper water column in the equatorial Atlantic Ocean, Palaeogeogr. Palaeoecol., 178, 53-66, 2002.

Weiser, J., Baumann, K.-H., Hahn, A., and Zabel, M.: Late Holocene paleoceanographic changes off south-western Africa as inferred from nannofossil assemblages, J. Nannoplankton Res., 36, 161-171, 2016.

WoRMS Editorial Board: An authoritative classification and catalogue of marine names, available at: http://www.marinespecies. org (last access: 1 November 2019), 2017.

Young, J., Geisen, M., Cross, L., Kleijne, A., Sprengel, C., Probert, I., and Østergaard, J.: A guide to extant coccolithophore taxonomy, J. Nannoplankton Res., Special Issue 1, International Nannoplankton Association, Druckstudio Digital Concept, Bremerhaven, Germany, 124 pp., 2003.

Young, J. R., Bown, P. R., and Lees, J. A.: Nannotax3 website, International Nannoplankton Association, available at: http://www. mikrotax.org/Nannotax3, last access: April 2019.

Zeeberg, J., Corten, A., Tjoe-Awie, P., Coca, J., and Hamady, B.: Climate modulates the effects of Sardinella aurita fisheries off Northwest Africa, Fish. Res., 89, 65-75, 2008.

Zenk, W., Klein, B., and Schröder, M.: Cape Verde Frontal Zone, Deep-Sea Res., 38, S505-S530, 1991.

Zonneveld, K. A. F. and Pospelova, V.: A determination key for modern dinoflagellate cysts, Palynology, 39, 387-409, 2015. 
Zonneveld, K. A. F., Susek, E., and Fischer, G.: Seasonal variability of the organic-walled dinoflagellate cyst production in the coastal upwelling region off Cape Blanc (Mauritania): a five-year survey, J. Phycol., 46, 202-215, 2010.

Zonneveld, K. A. F., Chen, L., Elshanawany, R., Fischer, H. W., Hoins, M., Ibrahim, M. I., Pittauerova, D., and Versteegh, G. J.: The use of dinoflagellate cysts to separate human-induced from natural variability in the trophic state of the Po River discharge plume over the last two centuries, Mar. Pollut. Bull., 64, 114132, 2012.

Zonneveld, K. A. F., Marret, F., Versteegh, G. J. M., Bogus, K., Bonnet, S., Bouimetarhan, I., Crouch, E., de Vernal, A., Elshanawany, R., Edwards, L., Esper, O., Forke, S., Grøsfjeld, K., Henry, M., Holzwarth, U., Kielt, J.-F., Kim, S.-Y., Ladouceur, S., Ledu, D., Chen, L., Limoges, A., Londeix, L., Lu, H., Mahmoud, M. S., Marino, G., Matsouka, K., Matthiessen, J., Mildenhal, C., Mudie, P., Neil, L., Pospelova, V., Qi, Y., Radi, T., Richerol, T., Rochon, A., Sangiorgi, F., Solignac, S., Turon, J.-L., Verleye, T., Wang, Y., Wang, Z., and Young, M.: Atlas of modern dinoflagellate cyst distribution based on 2405 datapoints, Rev. Palaeobot. Palynol., 191, 1-197, 2013.
Zonneveld, K. A. F., Ebersbach, F., Maeke, M., and Versteegh, G. J. M.: Transport of organic-walled dinoflagellate cysts in nepheloid layers off Cape Blanc (N-W Africa), Deep Sea Res. Pt. I, 139, 55-67, 2018. 